Article

\title{
Characteristics of the Wind and Wave Climate along the European Seas Focusing on the Main Maritime Routes
}

\author{
Ana-Maria Chirosca (D) and Liliana Rusu *(D)
}

Citation: Chirosca, A.-M.; Rusu, L. Characteristics of the Wind and Wave Climate along the European Seas Focusing on the Main Maritime Routes. J. Mar. Sci. Eng. 2022, 10, 75 . https://doi.org/10.3390/ jmse10010075

Academic Editor:

José-Santos López-Gutiérrez

Received: 19 December 2021

Accepted: 4 January 2022

Published: 7 January 2022

Publisher's Note: MDPI stays neutral with regard to jurisdictional claims in published maps and institutional affiliations.

Copyright: (C) 2022 by the authors. Licensee MDPI, Basel, Switzerland. This article is an open access article distributed under the terms and conditions of the Creative Commons Attribution (CC BY) license (https:// creativecommons.org/licenses/by/ $4.0 /)$.

\author{
Department of Mechanical Engineering, Faculty of Engineering, "Dunarea de Jos" University of Galati, \\ 47 Domneasca Street, 800008 Galati, Romania; ana.chirosca@ugal.ro \\ * Correspondence: liliana.rusu@ugal.ro
}

\begin{abstract}
European seas have a strong economic role both in terms of transport and tourism. Providing more knowledge, regarding the mean and extreme values of the wind and sea state conditions in the areas characterized by high maritime traffic, helps to improve navigational safety. From this perspective, six zones with high maritime traffic are studied. ERA5 database, a state-of-the-art global reanalysis dataset provided by ECMWF (European Centre for Medium-Range Weather Forecasts), is used to assess the average values and the percentiles for the wind speed and the main wave parameters in the target areas considering the period 2001-2020. The main European routes and the extreme conditions along them as well as the areas characterized by high values of wind speed and high waves were also identified. A more comprehensive picture of the expected dynamics of the environmental matrix along the most significant shipping routes is useful because in this way the most dangerous areas could be avoided by ships for the safety of passengers and transported goods.
\end{abstract}

Keywords: European seas; sea state conditions; wind climate; wave climate; statistical analysis

\section{Introduction}

The shipbuilding industry, especially the maritime traffic of both goods and people, has a considerable impact on the economy and technological evolution in the European sea basin. Even though the pandemic situation due to the Coronavirus virus (COVID-19) affected passenger transport during this period, freight transport continued to increase due to high market demand. For these reasons, it is necessary to investigate how maritime transport is carried out and what are the problems it faces, both in order to optimize it so that we can benefit from its advantages at maximum levels, but also to counteract various accidents at sea. For Europe, the transport of people, as well as goods and services, is a major sector that contributes to economic development and is constantly evolving in order to improve transport capacity, ship speed, port management time, safety, and security conditions.

One of the main factors that affect maritime transport is weather conditions, especially wind and wave parameters. Unfortunately, these parameters are constantly changing, and therefore have been the subject of several studies [1-3], in order to investigate how it behaves over the years and how climatic conditions evolve, but also to be able to perform predictions for their future behavior [4]. Another important aspect is the knowledge of the wind and wave climate that helps to reduce the number of accidents in areas prone to severe weather conditions, but also in coastal areas where due to congestion and limited space for various maneuvers, as well as limited water depth, the accident rate is higher [1].

At the same time, the study of wave and wind characteristics is of great interest for the offshore wind platform industry, which has begun to increase in number, especially in the North Sea area, where an offshore power grid is developing [5,6]. Climate change effects are reflected depending on the characteristics of each area, as well as the activities performed in each sea. Therefore, a detailed study of the present climate is needed to 
identify the changes in future climatic conditions [3], especially on the most frequented routes, in order to be able to counteract unfavorable navigation situations.

The European seas have various wind and wave climate characteristics. Thus, some of them are open seas and they have a direct connection with the Atlantic Ocean, and their wind and wave climate is strongly affected by the weather conditions in the ocean, while other seas are semi-closed basins where the wave climate is affected by local weather conditions. The Black Sea and the Baltic Sea, being semi-closed seas, are characterized by not very aggressive climatic conditions. In the Black Sea, only the eastern area is prone to the greatest swelling [7], but it is nevertheless an area suitable for maritime activities and operations [8]. Compared to the rest of the European seas, the Mediterranean Sea is most prone to severe climate change [9-11]. More information regarding the wind and wave climate in the Mediterranean Sea is presented in various studies, e.g., [12-14]. In the Baltic Sea and the North Sea, such conditions are met only in the autumn and winter seasons $[15,16]$.

The study of wind speed conditions is of great interest to the North Sea due to commercial interest, both due to the transport of goods and for the offshore industry [17], but a study of waves is not negligible due to the sea connection with North Atlantic Ocean [18]. Also, the wave climate and the changes observed in the last years affect the fatigue life of the offshore structure deployed in this sea [19]. The Norwegian Sea is also influenced by the North Atlantic Ocean and is facing several problems due to global warming and climate changes [20-22]. Thus, a decrease in mean wave height is projected in North Atlantic [23] and across most of the European coasts, with an increase in the annual maximum and 99th percentile wave height [24]. However, in some areas, an increase in waves is observed (e.g., north of Scotland) partly caused by the reduction in sea ice that induced an increased fetch for northerly winds [24]. One of the most important transport routes is located on the English Channel. The Strait of Dover separates the North Sea from the English Channel and is of great importance both in terms of transport ships and ferries $[25,26]$.

Considering the ones presented above, one objective of this study is to analyze the importance of the maritime traffic in the European seas, in terms of the total number of ships registered in ports, the number of passengers and the number of goods transported. The analysis is performed for a 20-year time interval (2001-2020). Taking into consideration the strong economic role of the European seas in terms of transport and tourism, it was considered of interest to carry out a study about the wind and wave climate that influence the safety and efficiency of navigation along the main routes crossing these seas. Thus, this paper presents also a study regarding the mean and extreme values of the wind and sea state conditions in the areas characterized by high maritime traffic during the same period (2001-2020).

The latest reanalysis data provided by the European Center for Medium-Range Weather Forecasts (ECMWF) were considered for this study, more details on the data used are given in the following sections where the wind and wave climate in target areas is analyzed in detail, together with studies regarding the extreme wind and wave conditions along the maritime routes.

\section{Marine Traffic}

Throughout the years 2001-2020, only two periods in which maritime transport suffered were identified, namely in the 2008-2009 period due to the financial crisis, and in the 2019-2020 period, due to the coronavirus pandemic (COVID-19). However, as the transport of goods and people both in Europe and internationally is a key factor for economic development but also for accessing goods globally, maritime traffic has recovered quickly after the end of these periods of crisis.

Maritime transport significantly influences the development of the European economy, due to the large number of passengers who choose this method of transport, as well as the level of goods transported, because it is the most preferred method of transport due to low 
prices and large quantities that can be shipped in only one trip. Due to the increased cargo volume transported by vessels, maritime shipping is among the most affordable ways to move goods.

Figure 1 shows an overview of the density of maritime traffic in European countries in 2019, for all months of the year (Figure 1a). To compare the differences in traffic between the months of the year (and also between various seasons), Figure $1 \mathrm{~b}$ shows the density map for June (summer season), and Figure 1c shows the density map for December (winter season). As expected, during the summer maritime traffic is much higher than in the winter, and the main reason is the increased number of passenger ships.
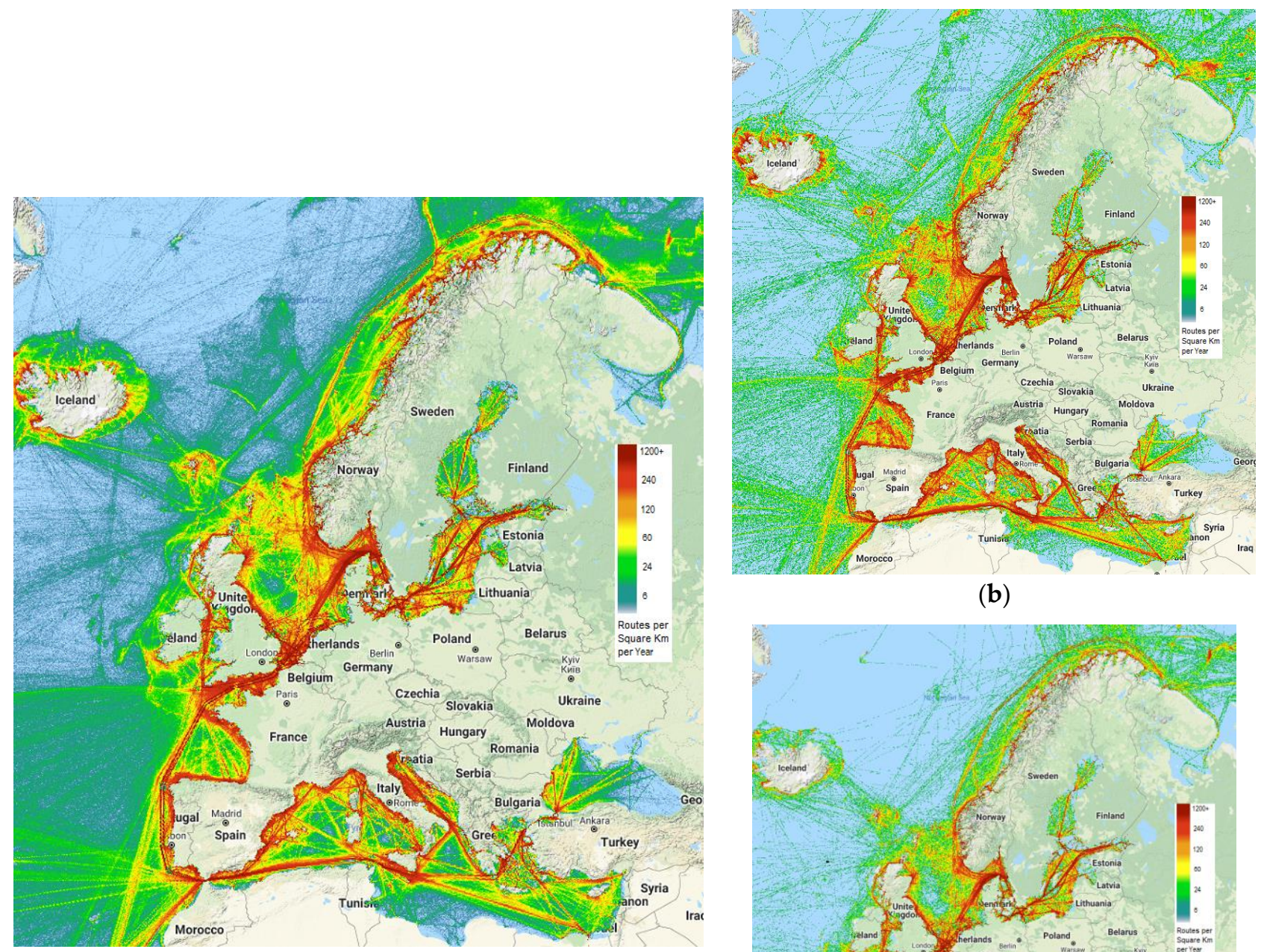

(b)

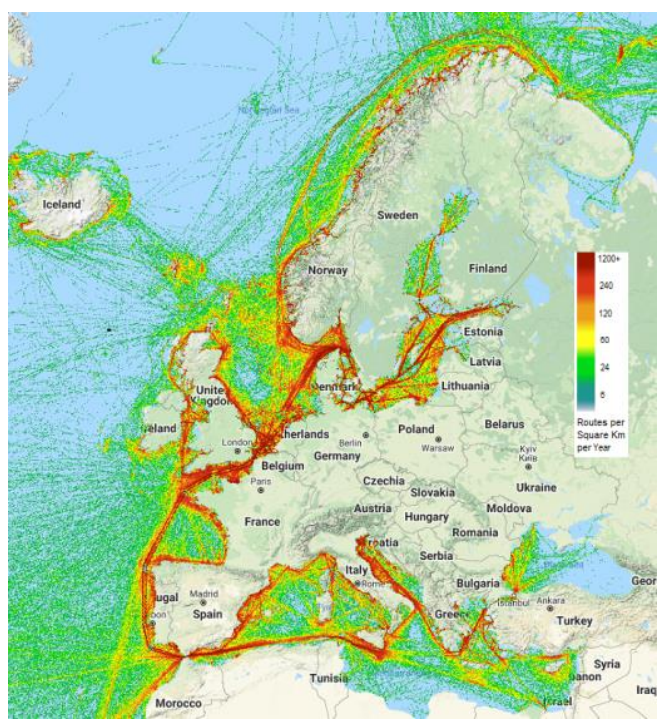

(a)

(c)

Figure 1. European Union vessel density map: (a) During the year 2019; (b) for July 2019; (c) for December 2019. [27].

The European Marine Observation and Data Network (EMODnet, [27]) platform was used to generate these maps that have been made from ship reporting data of the Automatic Identification System (AIS). As we can see, the maritime traffic is quite developed in Europe, especially in coastal regions and we find almost all types of existing ships. 
From the maps presented in Figure 1, it was observed that for various reasons (e.g., weather conditions, economical, geographical location, etc.), the maritime traffic has a higher density along certain routes. Furthermore, using the information provided by the World Meteorological Organization (WMO) through the interactive map of the Ship Observations Team (SOT, https:/ / www.ocean-ops.org/sot/, accessed on 12 December 2021) together with data from the Global Sipping Routes from the ArcGIS platform (https://www.arcgis.com/apps/mapviewer/index.html, accessed on 12 December 2021) the tracks of the core and secondary European routes were identified and they are presented in Figure 2. The seas crossed by these routes and their lengths are indicated in Table 1.

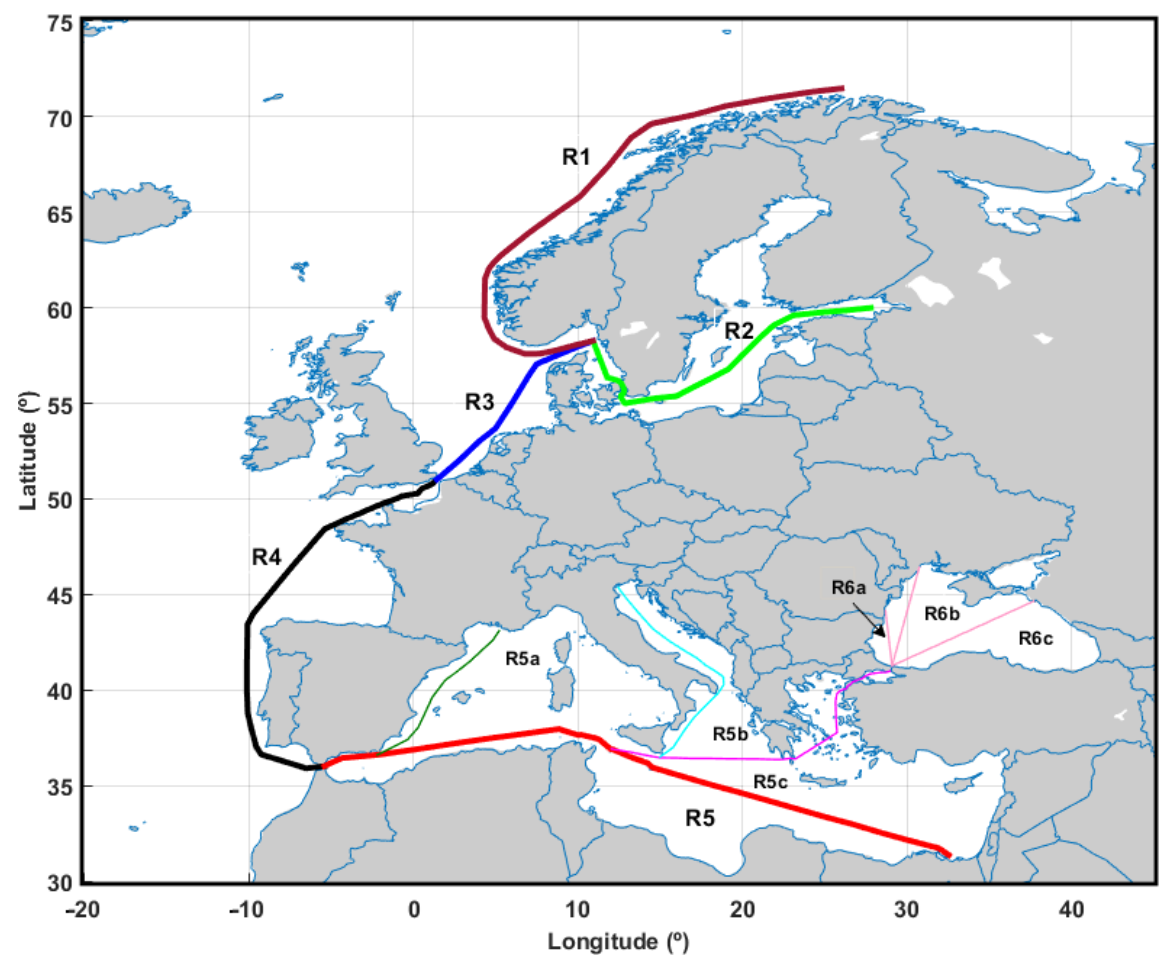

Figure 2. Tracks of the European routes (the main routes are represented with thicker lines, while the secondary routes are marked with thinner lines).

Table 1. Characteristics of the European routes.

\begin{tabular}{|c|c|c|c|}
\hline \multicolumn{2}{|c|}{ Routes } & Length (nmi) & Seas Crossed by the Route \\
\hline \multirow{5}{*}{ Main routes } & $\mathrm{R} 1$ & 1280 & Norwegian Sea \\
\hline & $\mathrm{R} 2$ & 814 & Baltic Sea \\
\hline & R3 & 585 & North Sea; Northern English Cannel \\
\hline & $\mathrm{R} 4$ & 1266 & $\begin{array}{l}\text { English Cannel; Bay of Biscay; } \\
\text { North Atlantic Ocean }\end{array}$ \\
\hline & R5 & 1911 & Mediterranean Sea \\
\hline \multirow{6}{*}{ Secondary routes } & $\mathrm{R} 5 \mathrm{a}$ & 487 & Western Mediterranean Sea; Gulf of Lion \\
\hline & $\mathrm{R} 5 \mathrm{~b}$ & 710 & Ionian Sea; Adriatic Sea \\
\hline & $\mathrm{R} 5 \mathrm{c}$ & 985 & $\begin{array}{c}\text { Sicilian Channel; Ionian Sea; Sea of Crete; } \\
\text { Aegean Sea; Marmara Sea }\end{array}$ \\
\hline & R6a & 178 & Western Black Sea \\
\hline & $\mathrm{R} 6 \mathrm{~b}$ & 323 & Western Black Sea \\
\hline & $\mathrm{R} 6 \mathrm{c}$ & 495 & Black Sea \\
\hline
\end{tabular}


The route R1 departs from the Skagerrak strait that connects the North Sea and the Kattegat Sea, following the Norwegian Trough and then the Scandinavian Peninsula coastline. From the same point starts also the route R2 that passes Copenhagen and reaches the Gulf of Finland, and the route R3 that crosses the North Sea until the Strait of Dover. Route R4 is one of the intense routes, connecting the British Channel (from the Strait of Dover) with the Strait of Gibraltar and then through route R5 with the Suez Canal. In the Mediterranean Sea, in addition to the main route R5, three secondary routes have been identified: route R5a follows the south of the Iberian Peninsula until Marseilles, route R5b departs from the southern coast of Sicily, crosses the Adriatic Sea, and arrives at Venice, and route $\mathrm{R} 5 \mathrm{c}$ connects the main route R5 with the Bosporus Strait. In the Black Sea, three secondary routes are defined, all of them depart from Bosporus Strait and connect the main ports of this basin (R6a-Constanta port, R6b-Odesa port, R6c-Novorossiysk) with the main European routes. Apart from the route R4 and route R5, which are two of the busiest sea routes in the world, the connection between the route R1 and the route R2, represented by the Skagerrak Strait, is of great interest because it is the gateway between the Baltic Sea and the North Sea.

In recent years, there has been a trend to improve the characteristics of transport vessels and port infrastructure [28]. Especially in the case of container ships, it is desired to improve the loading capacity of this type of ship, its travel speed as well as to increase the travel distance. At the same time, the development of port infrastructure is also necessary to make it possible for high-capacity ships to be introduced on regular routes and used over shorter distances.

Based on data provided by Eurostat, the statistical office of the European Union [29] which provides statistical data on Europe up to date, the maritime traffic for the period 2001-2020 was investigated. The total number of ships registered for the period 2001-2020 period in European countries (Figure 3) was 44,539,687 vessels, and during the 20 years studied we can observe a slight upward trend from the beginning of the period to the end of the period, with small exceptions in a few years.

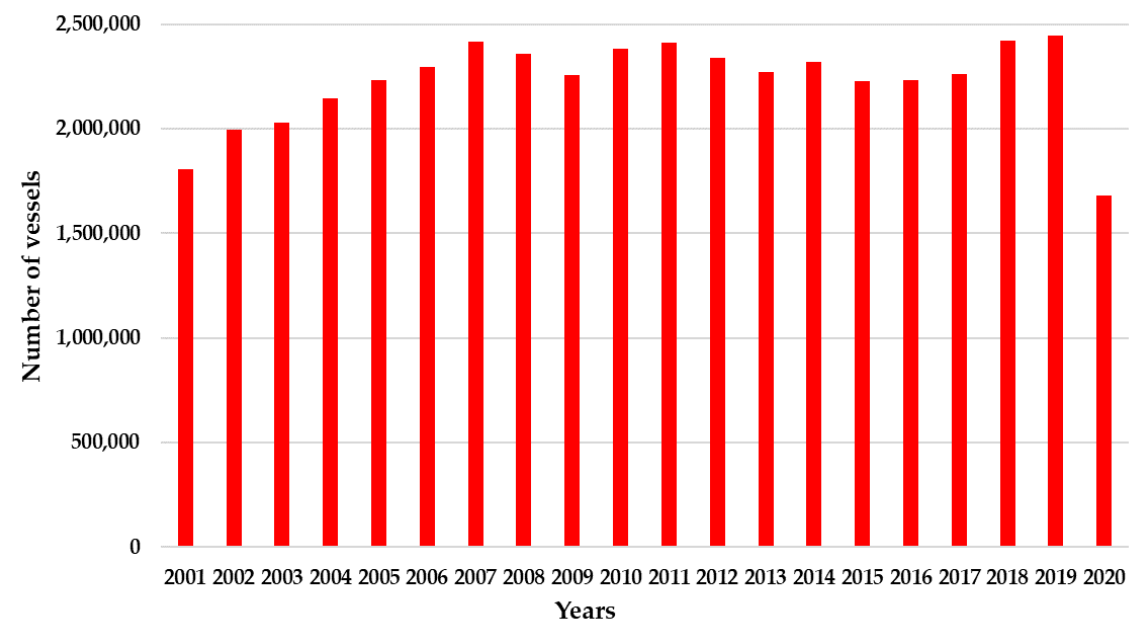

Figure 3. Total number of vessels in the main ports of European countries for the period 2001-2020.

Reported annually, the highest number of ships registered in the main ports was in 2019, when a total number of 2,447,421 ships were recorded, and the lowest number of ships was recorded in 2020 when they were registered with $30 \%$ fewer ships due to the crisis caused by the COVID-19 virus.

A major factor in shipping is the routes on which goods or people travel. Some routes are popular throughout the year, such as those arriving in the port of Rotterdam, which is the most important port for shipping and ranks first in terms of the gross weight of goods handled in each port [30]. Other routes, although they have races throughout the year, 
become much more popular in the summer season, due to cruise passengers or tourists, such as routes in the Mediterranean Sea area.

From the point of view of the ranking of the countries in which the most vessels were registered, Italy takes the lead with $20.44 \%$ of the total number of ships, followed by Greece with $19.73 \%$ and Denmark with $15.38 \%$, as we can see in Figure 4 .

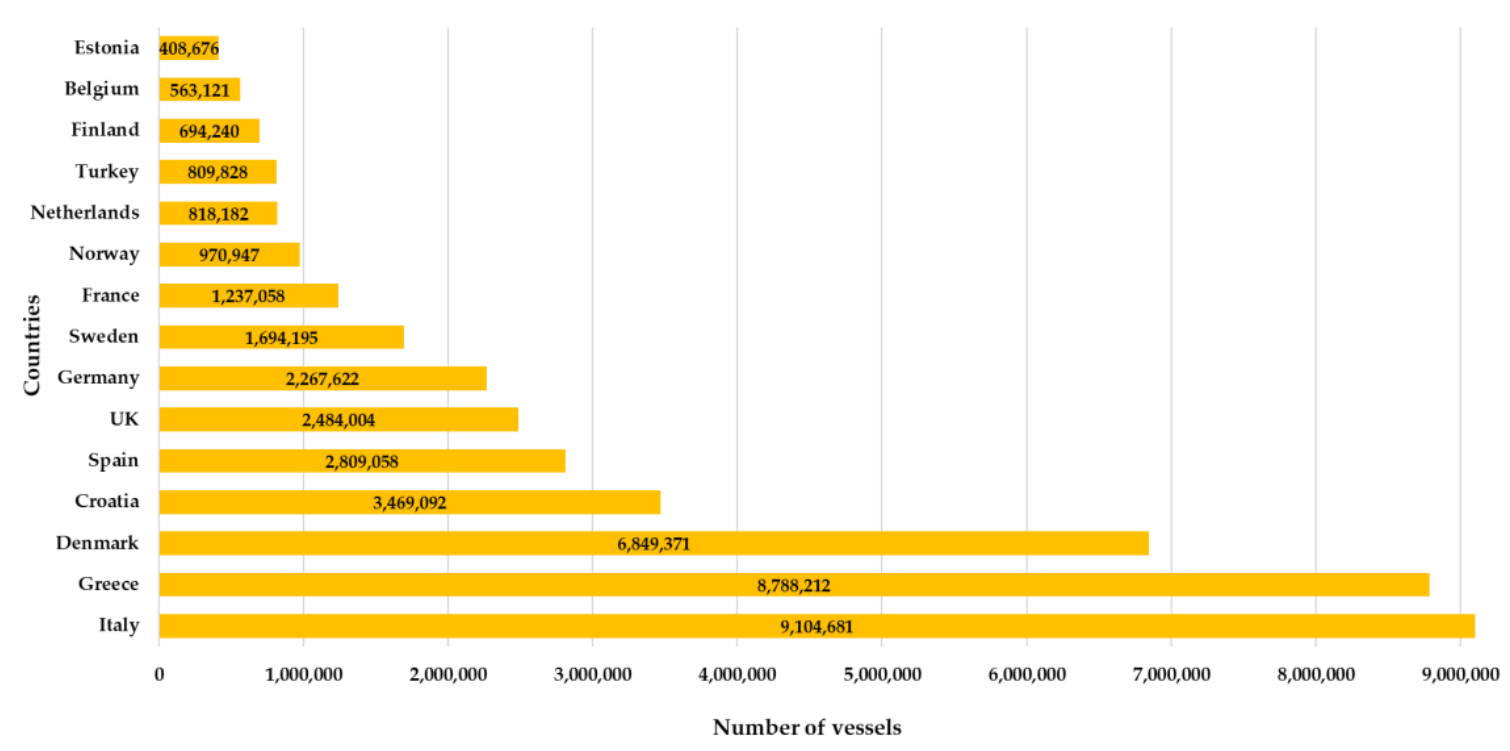

Figure 4. Top 15 European countries regarding the number of vessels registered in the period 2001-2020.

During the years 2001-2020, 83,002,314 thousand tons gross weight of goods were transited (Figure 5). Inbound goods were 10\% more than outbound goods out of total goods transited. As we can see in Figure 6, for the studied period, most goods were registered in the Netherlands (12.58\%) and the United Kingdom (12.35\%) and Italy $(11.55 \%)$ in the 2nd and 3rd place, respectively, and followed very closely by Spain $(9.92 \%)$.

Total Inbound $\quad$ Outbound

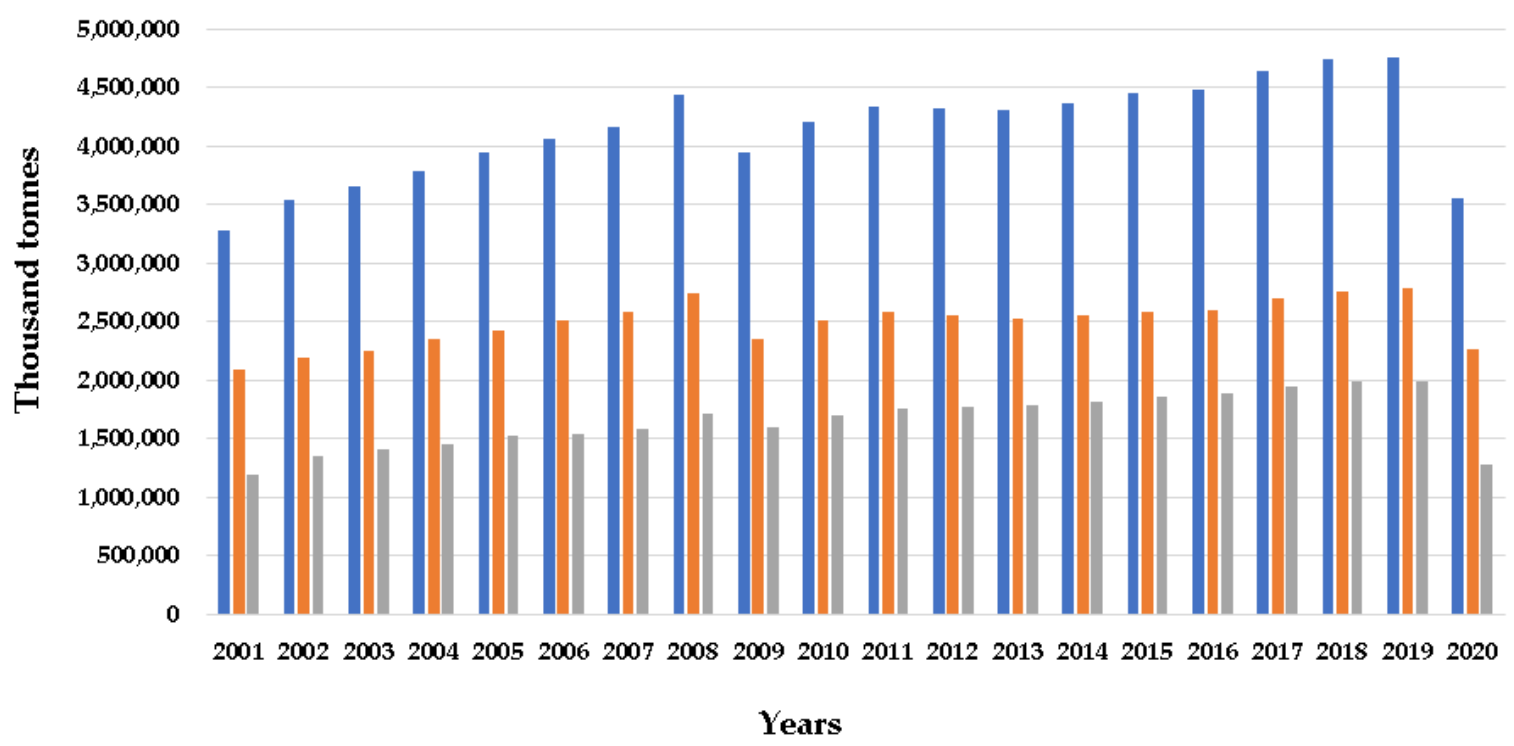

Figure 5. The gross weight of goods handled for the period 2001-2020. 


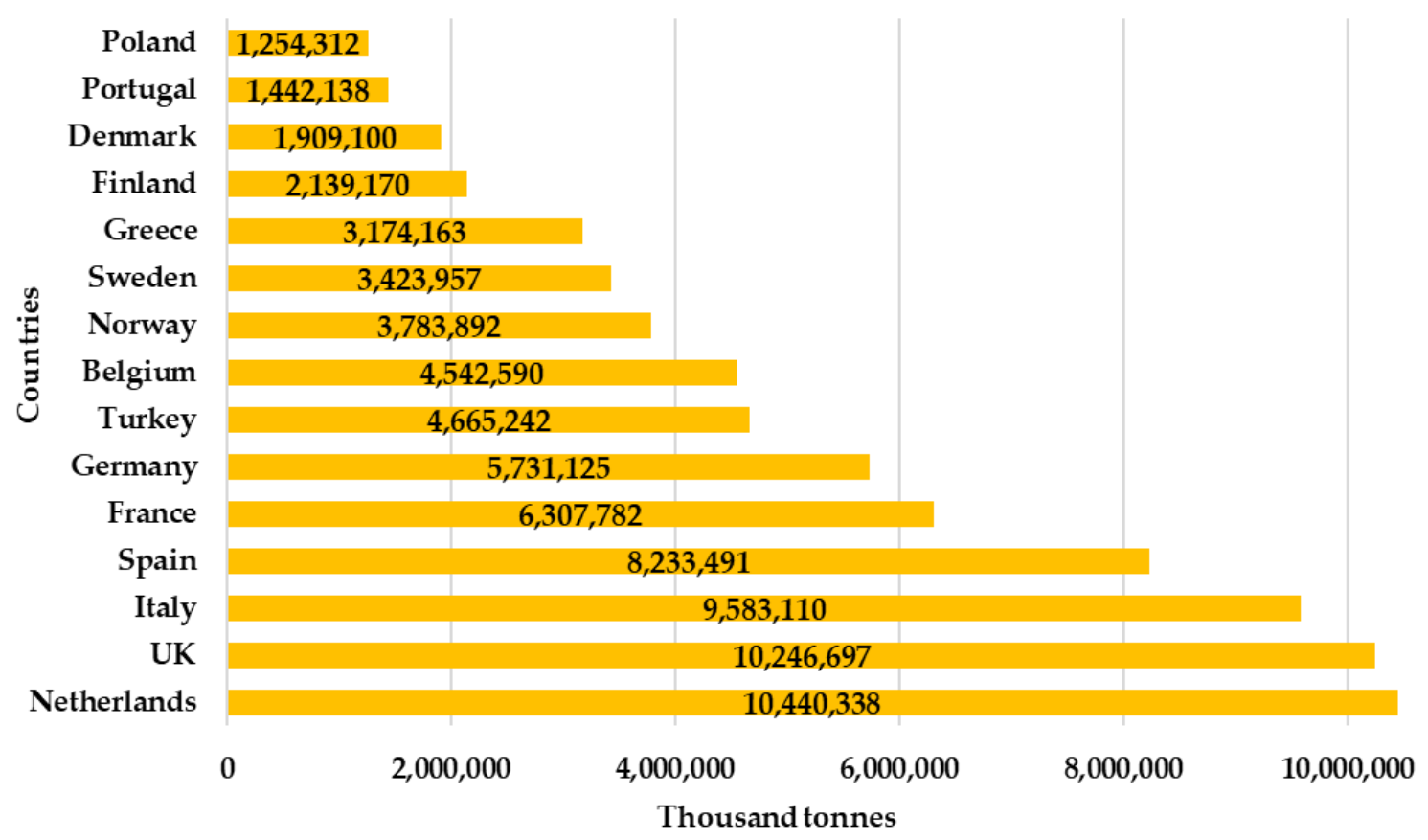

Figure 6. Top 15 European countries regarding the number of goods registered in the period 2001-2020.

After cargo ships, the second most predominant type of ship, in the basin of the European seas, is that of passenger ships. A total of 5,501,141 thousand passengers excluding cruise passengers was registered in the European sea area during the period 2001-2020 (Figure 7).

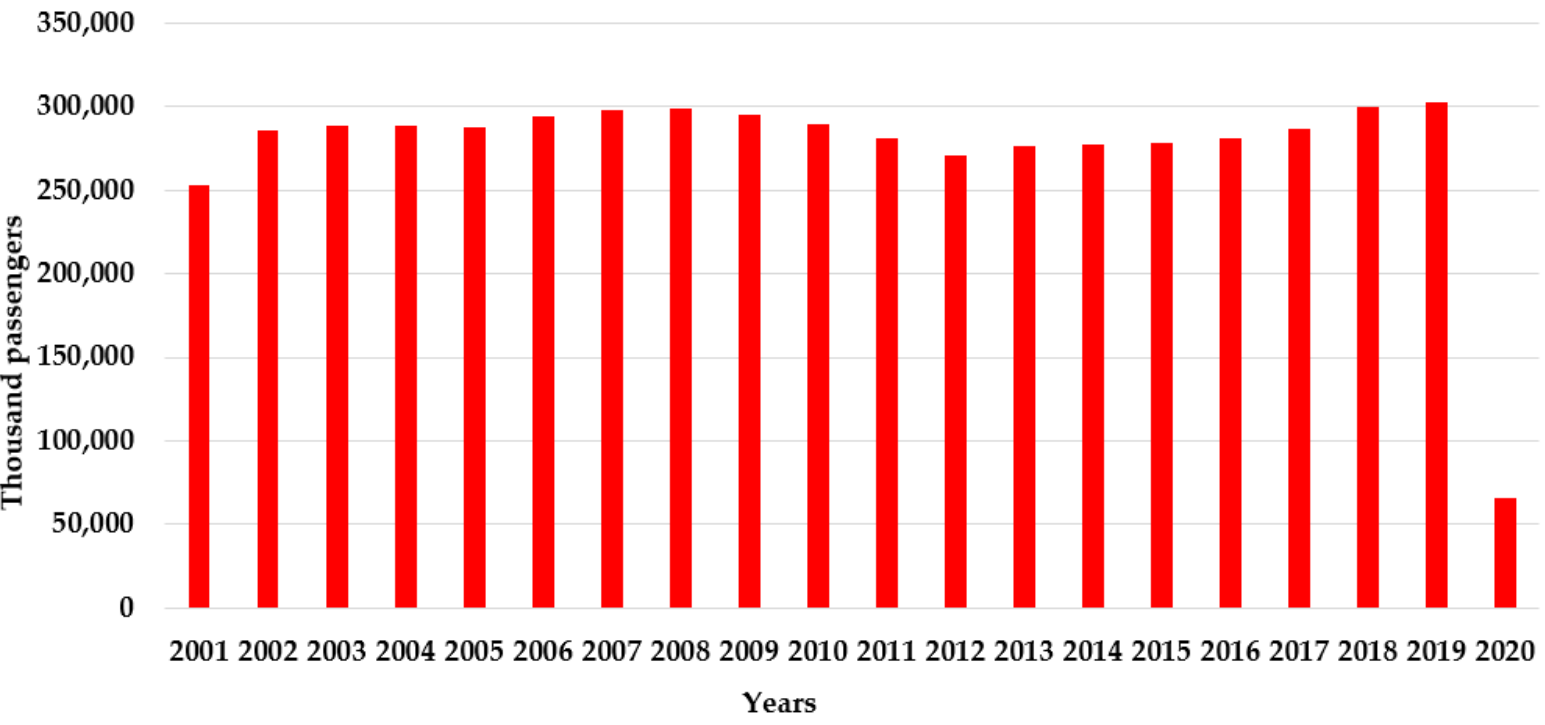

Figure 7. Total passengers transported to/from main ports of European countries for the period 2001-2020.

The countries with the most passengers recorded were (Figure 8) Italy, Greece and Denmark. The pandemic crisis' impact was seen most in passenger traffic, decreasing considerably by about $80 \%$ compared to 2019 .

The most popular routes for the transport of goods and people cross areas where climatic conditions are constantly changing, and therefore a study on wind and wave climate is required along them, together with the assessment of the extreme condition. In the following section analyses of the wind and wave climate will be performed in the European seas and along the maritime routes defined in Figure 2. 


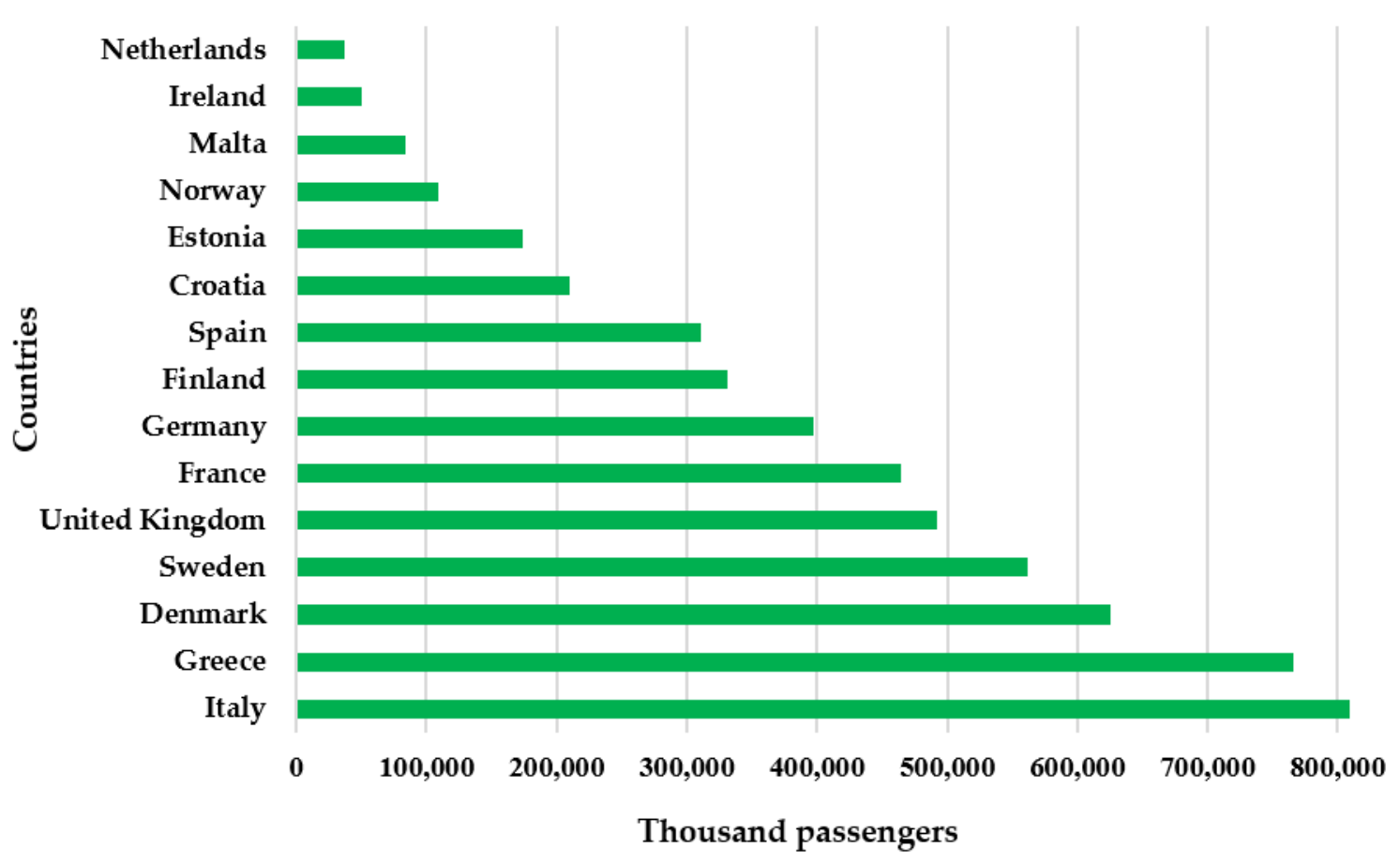

Figure 8. Top 15 countries of European countries regarding the number of passengers for the period 2001-2020.

\section{Data Used in the Climate Analysis}

The study of climatic conditions for wind and waves was performed using data extracted from the ERA5 database [31,32]. ERA5 data provided by the Copernicus Climate Change Service (C3S) at ECMWF represents a new generation reanalysis for global climate and weather in recent decades. This database has a significantly improved horizontal resolution compared to ERA-Interim [33] (previous reanalysis data provided by ECMWF) and is based on the Cy41r2 Integrated Forecasting System (IFS). Another series of improvements over ERA-Interim is information on variation in quality over space and time, improved representation of tropical cyclones, better precipitation over land in the deep tropics, more consistent sea surface temperature and sea ice, and many others [32].

ERA5 provides hourly estimates for several atmospheric parameters, both for land and sea dust, and covers the period from 1979 to the present. For this study, every $3 \mathrm{~h}$ wind data were extracted on single levels for the period 2001-2020, as well as the main wave parameters (significant height of combined wind waves and swell-Hs and mean zero-crossing wave period-Tm). The spatial resolution of the wind fields is $0.25^{\circ}$, while the wave parameters are provided with a resolution of $0.5^{\circ}$, both in latitude and longitude.

Six zones with high maritime traffic were considered to study the wind and wave climate (see Figure 9), and three of them are semi-enclosed seas (Mediterranean Sea, Black Sea, and Baltic Sea). Three other zones are marked in Figure 9, and they cover the Norwegian and North seas and a zone hereinafter referred to as the English Channel, which includes the channel with the same name and also the Celtic Sea. In these zones are some of the most important ports in Europe. The areas of the semi-enclosed seas were not marked as in the case of the other three target areas because their basins are clearly delimited on the map by the surrounding coasts. The characteristics of the geographical domains considered to analyze wind and wave climate are presented in Table 2, together with some characteristics of the seas covered by them. 


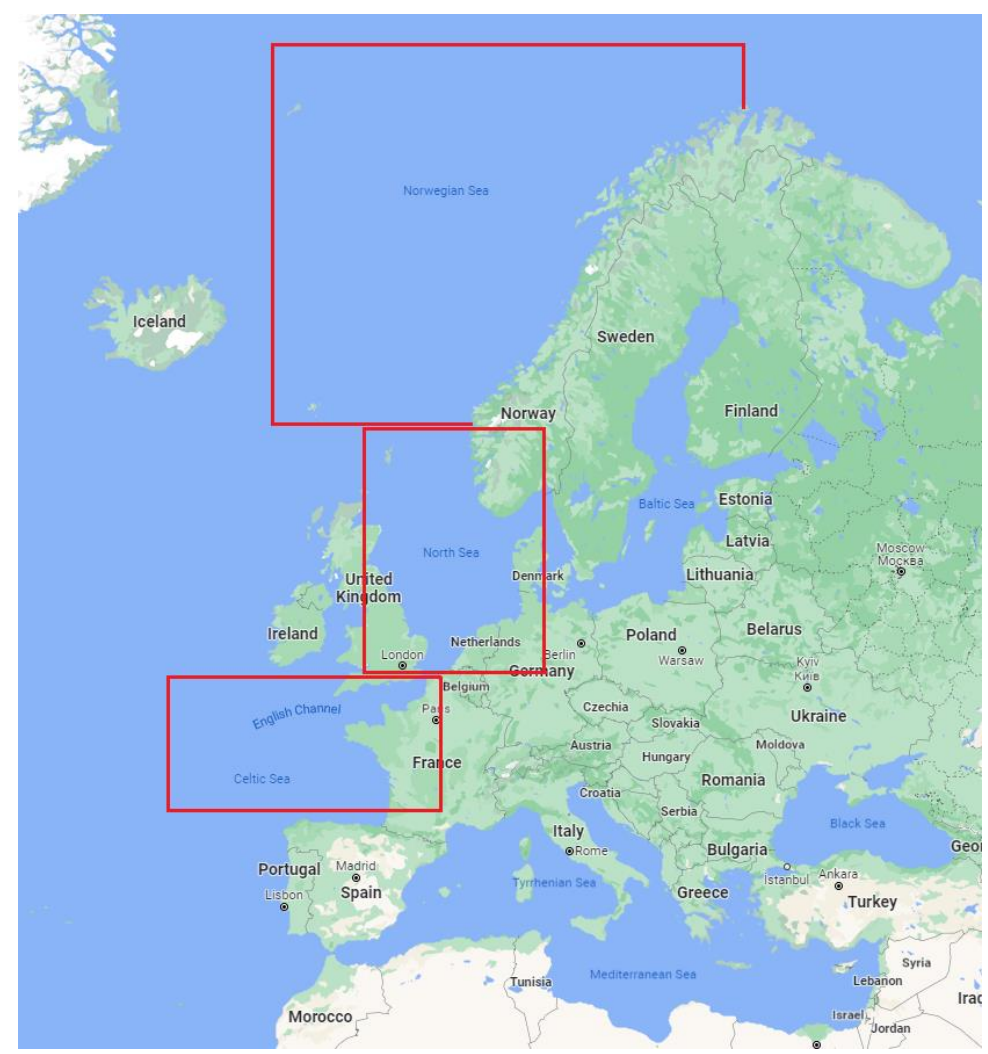

Figure 9. The geographical zones investigated in the study (figure processed from Google Maps).

Table 2. Main characteristics of the geographical zones considered in this study.

\begin{tabular}{ccccc}
\hline Zone & Coordinates & Surface Area & Average Depth & Maximum Depth \\
\hline Black Sea & $27^{\circ} \mathrm{E}-42^{\circ} \mathrm{E} / 41^{\circ} \mathrm{N}-47^{\circ} \mathrm{N}$ & $436,402 \mathrm{~km}^{2}$ & $1253 \mathrm{~m}$ & $2212 \mathrm{~m}$ \\
Mediterranean Sea & $5^{\circ} \mathrm{W}-35^{\circ} \mathrm{E} / 30^{\circ} \mathrm{N}-40^{\circ} \mathrm{N}$ & $2,500,000 \mathrm{~km}^{2}$ & $1500 \mathrm{~m}$ & $5267 \mathrm{~m}$ \\
English Channel & $15^{\circ} \mathrm{W}-10^{\circ} \mathrm{E} / 45^{\circ} \mathrm{N}-51^{\circ} \mathrm{N}$, & $375,000 \mathrm{~km}^{2}$ & $63 \mathrm{~m}$ & $174 \mathrm{~m}$ \\
North Sea & $5^{\circ} \mathrm{W}-10^{\circ} \mathrm{E} / 51^{\circ} \mathrm{N}-60^{\circ} \mathrm{N}$, & $570,000 \mathrm{~km}^{2}$ & $95 \mathrm{~m}$ & $700 \mathrm{~m}$ \\
Baltic Sea & $12^{\circ} \mathrm{E}-32^{\circ} \mathrm{E} / 53^{\circ} \mathrm{N}-65^{\circ} \mathrm{N}$, & $377,000 \mathrm{~km}^{2}$ & $55 \mathrm{~m}$ & $459 \mathrm{~m}$ \\
Norwegian Sea & $10^{\circ} \mathrm{W}-25^{\circ} \mathrm{E} / 60.5^{\circ} \mathrm{N}-74^{\circ} \mathrm{N}$ & $1,380,000 \mathrm{~km}^{2}$ & $2000 \mathrm{~m}$ & $3970 \mathrm{~m}$ \\
\hline
\end{tabular}

\section{Analysis of Wind Climate}

\subsection{Wind Climate in the European Seas}

To study wind speed (V), the $10 \mathrm{~m}$ u-component of wind and $10 \mathrm{~m} \mathrm{v}$-components of wind were extracted from the ERA5 database for the considered period, and the magnitude of wind speed at $10 \mathrm{~m}$ above the sea level was calculated as follows:

$$
\mathrm{V}=\sqrt{\mathrm{u}^{2}+\mathrm{v}^{2}}[\mathrm{~m} / \mathrm{s}]
$$

The 3-h resolution time series of wind speed at each point of the wind field, over the 20 years studied, were averaged. The mean values of the wind speed for the period 2001-2020 are presented in Figure 10. The maximum mean value of wind speed in the region of Europe is around $9.81 \mathrm{~m} / \mathrm{s}$ and as expected it is located on the western side of the area, toward the North Atlantic Ocean. It should be mentioned here that in all following maps, where a climatic analysis is represented, the position of the maximum value of the field is marked with a black circle. 


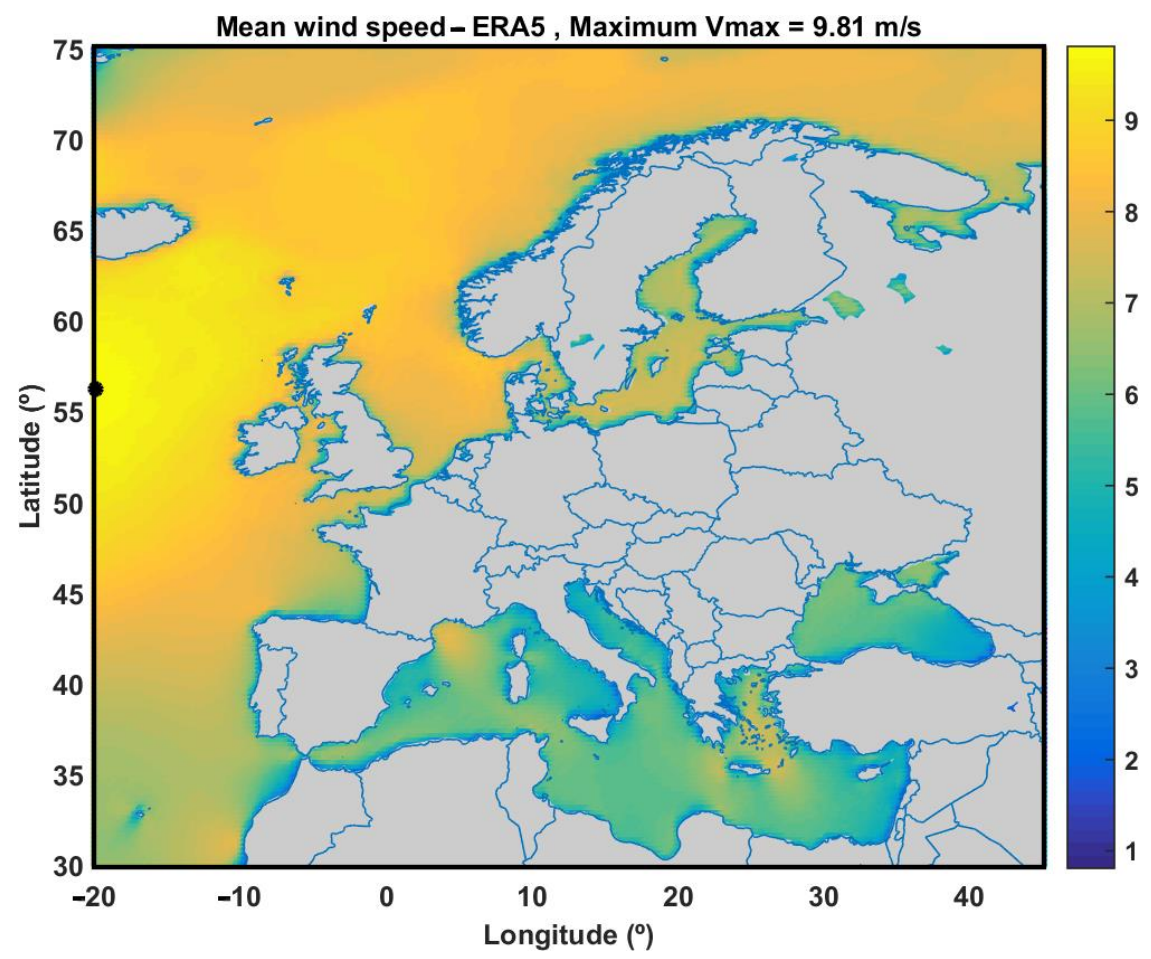

Figure 10. Mean wind speed for the Europe area.

In the north-western European seas, namely the Norwegian Sea, the North Sea, and England Channel, in general, the highest averages of wind speed are found, where the maximum mean values reach even $9 \mathrm{~m} / \mathrm{s}$. For these reasons, the North Sea area is popular in terms of installing wind platforms, due to the favorable wind conditions, but also low water depth [34]. Also, on the northern coast of Brittany, high winds are found, mainly due to the channeling effect of the English Channel [35]. The Norwegian Sea is also characterized by high wind speeds [36], and projections of future wind speeds show that these high values will be maintained [37].

Lower mean values were found in the Black Sea area, but this area also has some regions with very good offshore wind energy potential as shown in various studies [38-40]. Moreover, the projections of the future wind conditions show an increase in wind speeds in the coastal environment of the Black Sea, especially on the western side of the basin [41].

The mean values of the wind speed in the Mediterranean Sea are comparable with those encountered in the Black Sea. However, there are some areas where the average values are higher, reaching maximum values ranging between $8-8.5 \mathrm{~m} / \mathrm{s}$. As observed in various studies [42,43], these areas are the Gulf of Lion and the Aegean Sea.

For the seasonal variation analysis of the mean wind speed, the usual quarterly partition for the months of the year was considered (DJF: December-January-February, MAM: March-April-May, JJA: June-July-August, SON: September-October-November) and the results are shown in Figure 11 (the same colorbar is used for all panels). One unified colormap that covers the range of values across all four maps will help us to better observe the seasonal variability of the mean wind speed.

Figure 11 clearly indicates the seasonal evolution of the mean wind speed, the windiest season is the winter (DJF), while the calmest wind conditions are usually in the summer months (JJA). In winter the mean wind speed reaches values around $10 \mathrm{~m} / \mathrm{s}$ near to the western European coasts and along the routes crossing these areas. The mean wind speed field in intermediate seasons (spring and autumn) present similar patterns, with slightly higher values in autumn, while in summer the mean wind speed drops by about $40 \%$ the values seen in winter. An unusual feature appears in the Aegean Sea in July and August when the Etesian winds prevail over the area, with dry and relatively cool air masses originating from the region of Russia and the Caspian Sea [42]. 

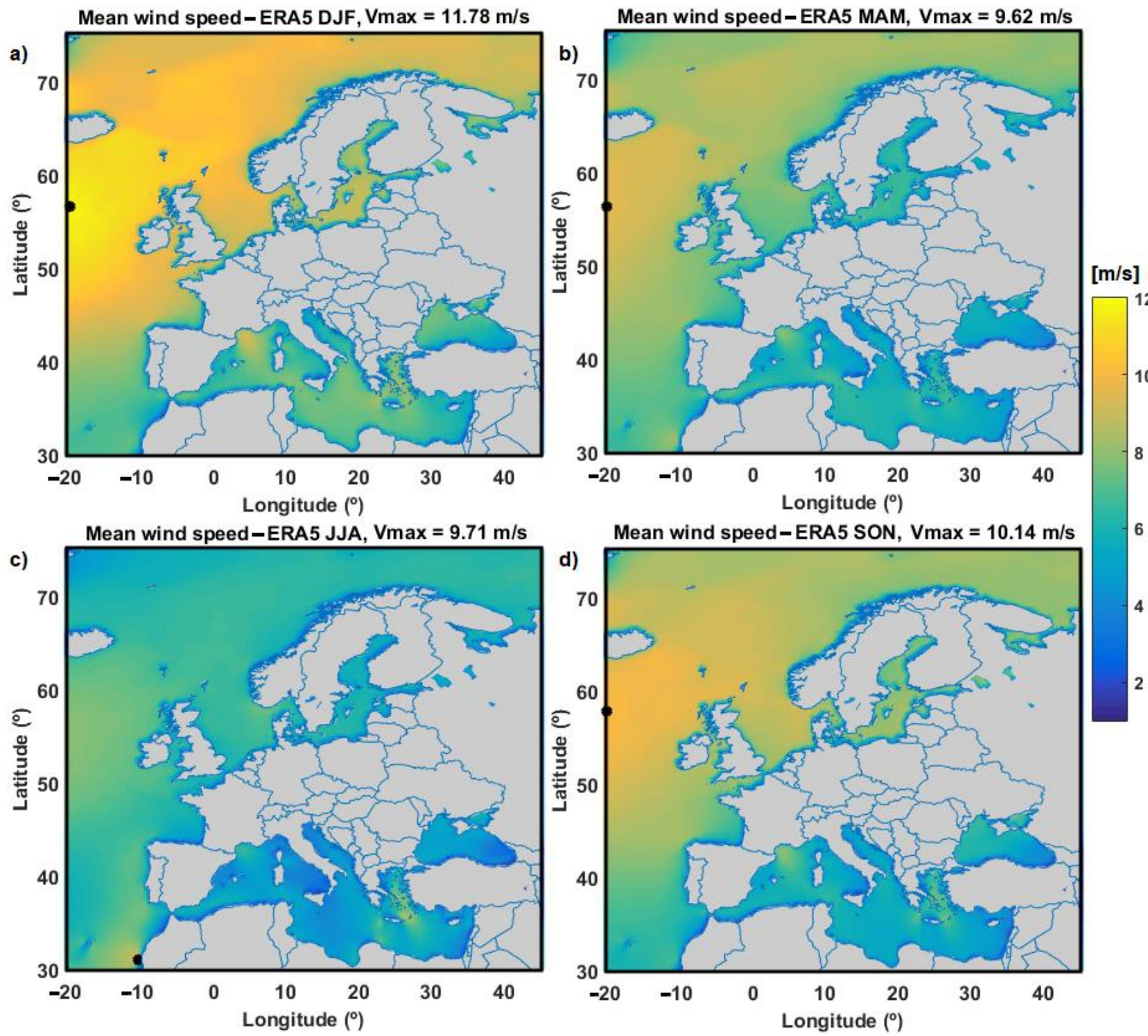

Figure 11. Seasonal variability of the mean wind speed over the 20-year time interval (from 2001 to 2020) based on ERA5 data: (a) winter (DJF), (b) spring (MAM), (c) summer (JJA), (d) autumn (SON).

An image of the statistical distribution of a certain parameter analyzed over a time interval is provided through the computation of the percentiles. The 50 th, 75 th, 90 th, and 95th percentiles of the wind speed based on ERA5 data over the 20-year interval considered are also computed using the Matlab function dedicated to this and the results are illustrated as maps. This allows for the analysis of the data in terms of percentages and an image of the extreme values encountered in the studied areas. Thus, the 95th percentile indicates the value below which $95 \%$ of the data are found, and above which are only 5\%. The 50th percentile represents the median of the distribution (or second quartile Q2), while the 75th percentile is the third quartile (Q3). The results obtained for the 20-years period considered in this study are presented as maps for entire Europe in Figure 12.

In general, the maps for the 50th and 75th percentiles have a similar distribution, with wind speeds not exceeding $8.5 \mathrm{~m} / \mathrm{s}$ and $11 \mathrm{~m} / \mathrm{s}$, respectively, near western European coasts, while the maximum values $(9.61 \mathrm{~m} / \mathrm{s}$ and $12.75 \mathrm{~m} / \mathrm{s})$ are located far to the coast, on the western side of the Europe zone. In the case of the 90th and 95th percentiles, the higher wind magnitudes are moving to the northern part, as also indicated by the location of the maximum values. 

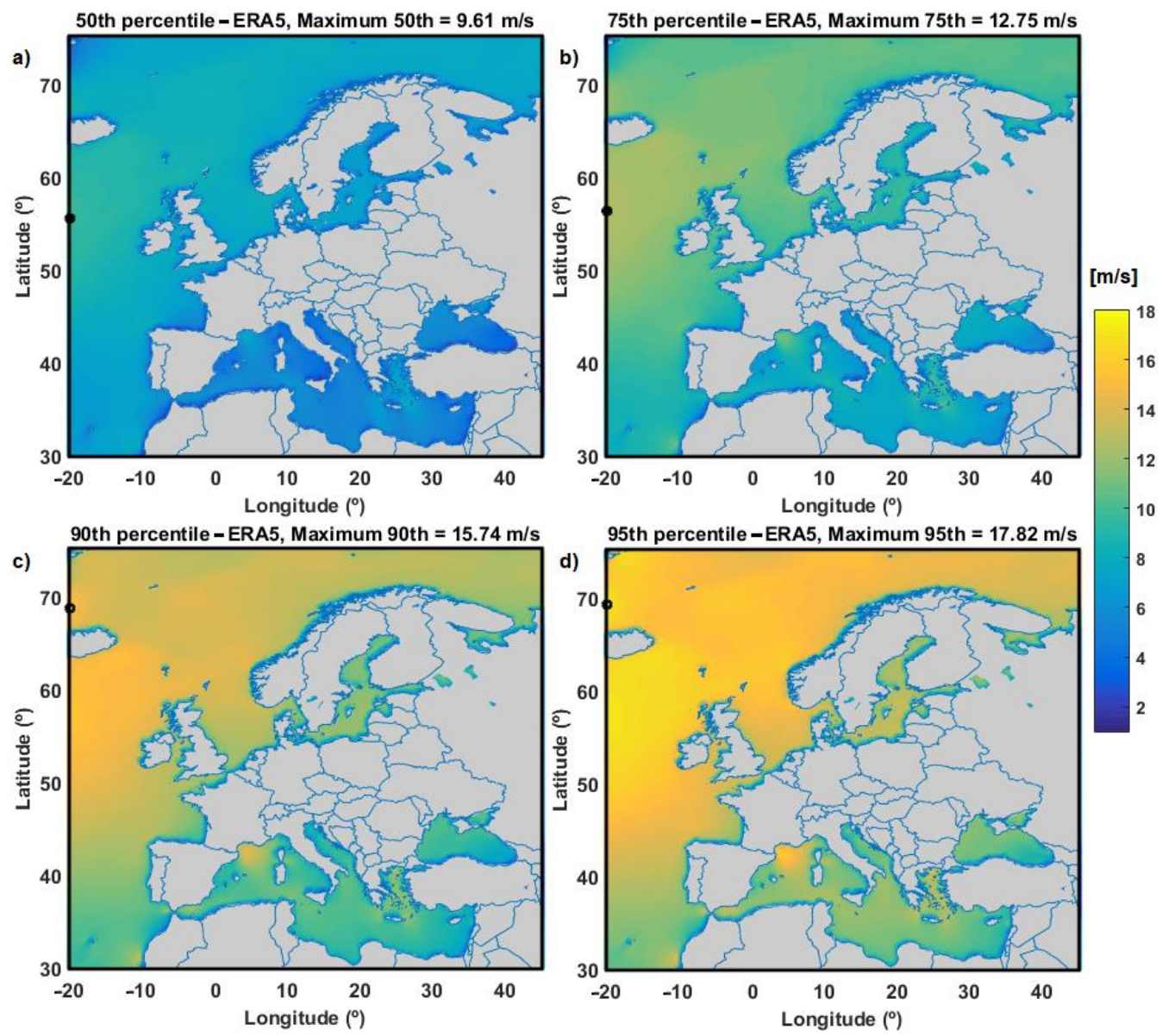

Figure 12. Statistical investigation on wind speed: (a) 50th percentile; (b) 75th percentile; (c) 90th percentile; (d) 95 th percentile.

\subsection{Extreme Wind Conditions along the Maritime Routes}

The extreme wind conditions at $10 \mathrm{~m}$ above the sea level, represented by the wind speed 95th percentiles, were extracted along the maritime routes and the results are presented in Figure 13. The maximum value of the 95th percentile on each route was computed and they are given in Table 3.

Table 3. Maximum wind speed 95th percentile on each route considered in this study.

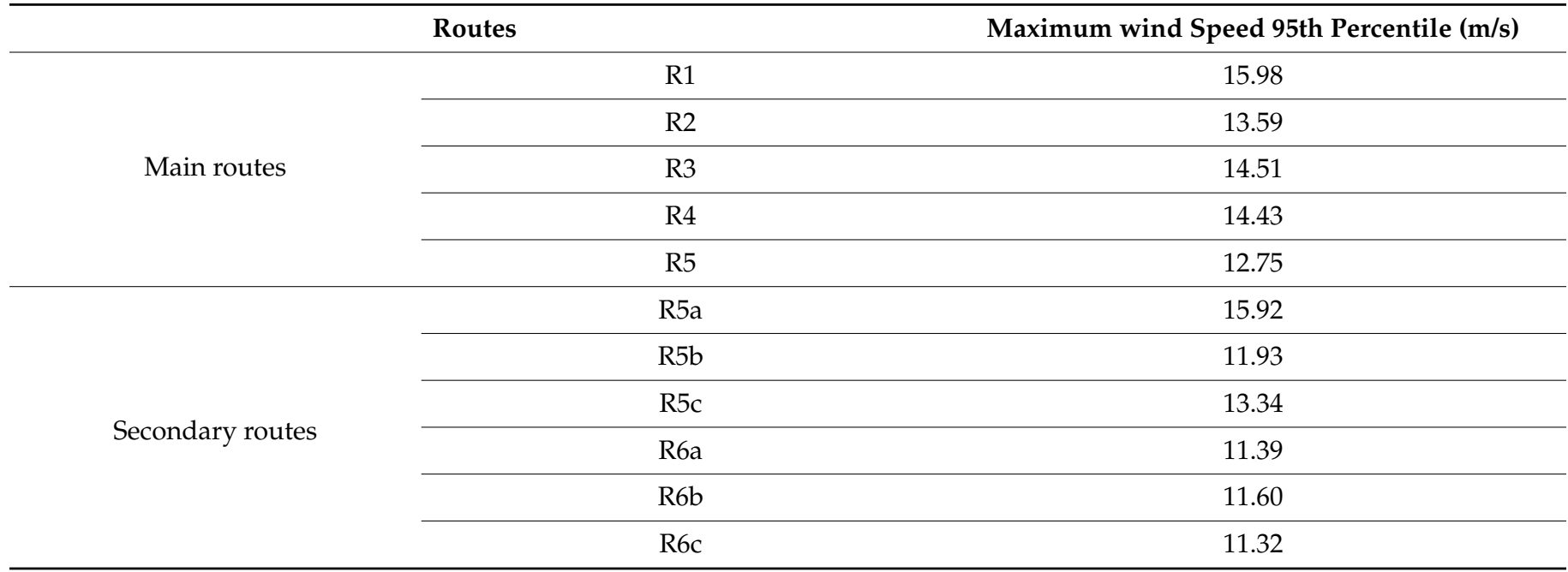




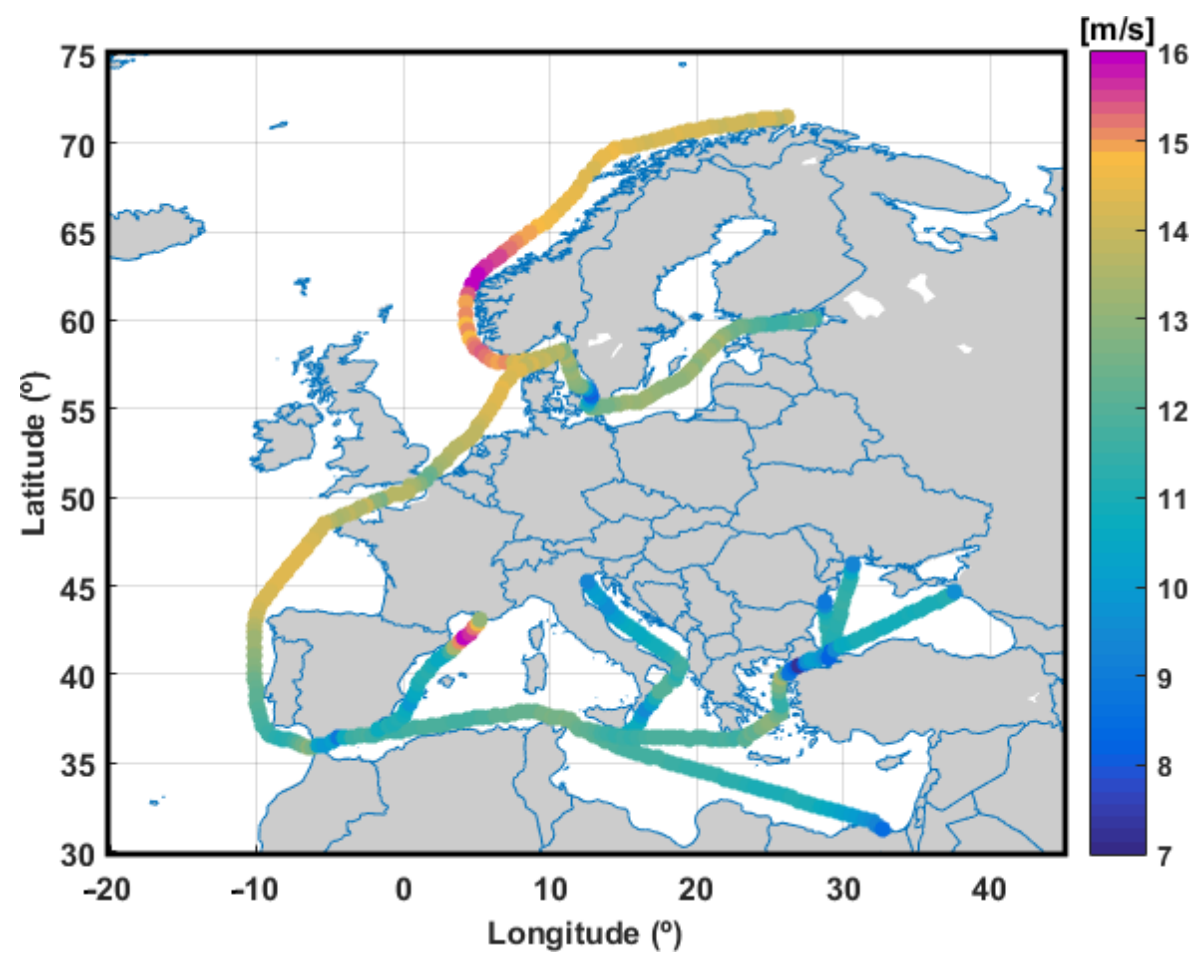

Figure 13. Wind speed 95th percentile along the European maritime routes.

As can be observed from Table 3 and Figure 13, the highest values (above $15 \mathrm{~m} / \mathrm{s}$ ) of the wind speed 95th percentile are on routes R1 and R5a (in Gulf of Lion). On route R3 and the northern part of route $\mathrm{R} 4$ maximum values around $14.5 \mathrm{~m} / \mathrm{s}$ can be found.

\section{Analysis of Wave Climate}

\subsection{Wave Climate in the European Seas}

Regarding the sea state conditions, they were analyzed from the perspective of the two main wave parameters (Hs and $\mathrm{Tm}$ ) which are also important in the analysis of ship dynamics and influence the operability of vessels. As in the case of wind analyses, for the Europe zone, the mean values of both wave parameters were calculated (Figure 14). An analysis of the mean fields for both parameters was also made for each zone. The importance of knowing the wave climate along the maritime routes has been mentioned in various studies, e.g., [1,44].

For the Europe zone, the mean values computed using data covering the twenty years have a maximum value of $3.48 \mathrm{~m}$ for $\mathrm{Hs}$ and $6.85 \mathrm{~s}$ for $\mathrm{Tm}$. As expected, the lowest value of the maximum mean Hs was found in the Black Sea $(0.97 \mathrm{~m})$ and the highest maximum mean Hs in the English Channel $(3.14 \mathrm{~m}$ ) being located in the northwest corner of the area, followed by the Norwegian Sea, North Sea, Mediterranean Sea and Baltic Sea. The same order is also maintained in the case of Tm.

The maximum value of the Hs mean is higher with about 30\% than the 95th percentile of the field in the North Sea, while in the other seas and whole of Europe these are higher with about $4 \%$. This high difference shows that there are some extreme values in certain areas compared with the behavior of the whole basin. The maps indicate that at the northern part of the North Sea basin the waves are affected by the swell coming from North Atlantic Ocean, and for this reason the highest values of the Hs are encountered here, while in the rest of the basin the Hs means do not exceed $2.3 \mathrm{~m}$. In the case of the mean wave period, the highest mean values are found in the English Channel zone, being influenced by the swell affecting the Celtic Sea waves.

Given that in the northern hemisphere there is a greater seasonal variability of the wave climate than in the southern hemisphere [45-47], the next step was to perform an 
analysis of the seasonality of the wave climate in the target areas. and the results obtained for both wave parameters are presented in Figures 15 and 16. A seasonal analysis of the maximum percentiles of the mean fields encountered in each sea was also performed only for $\mathrm{Hs}$ and the results are presented in Figure 17.
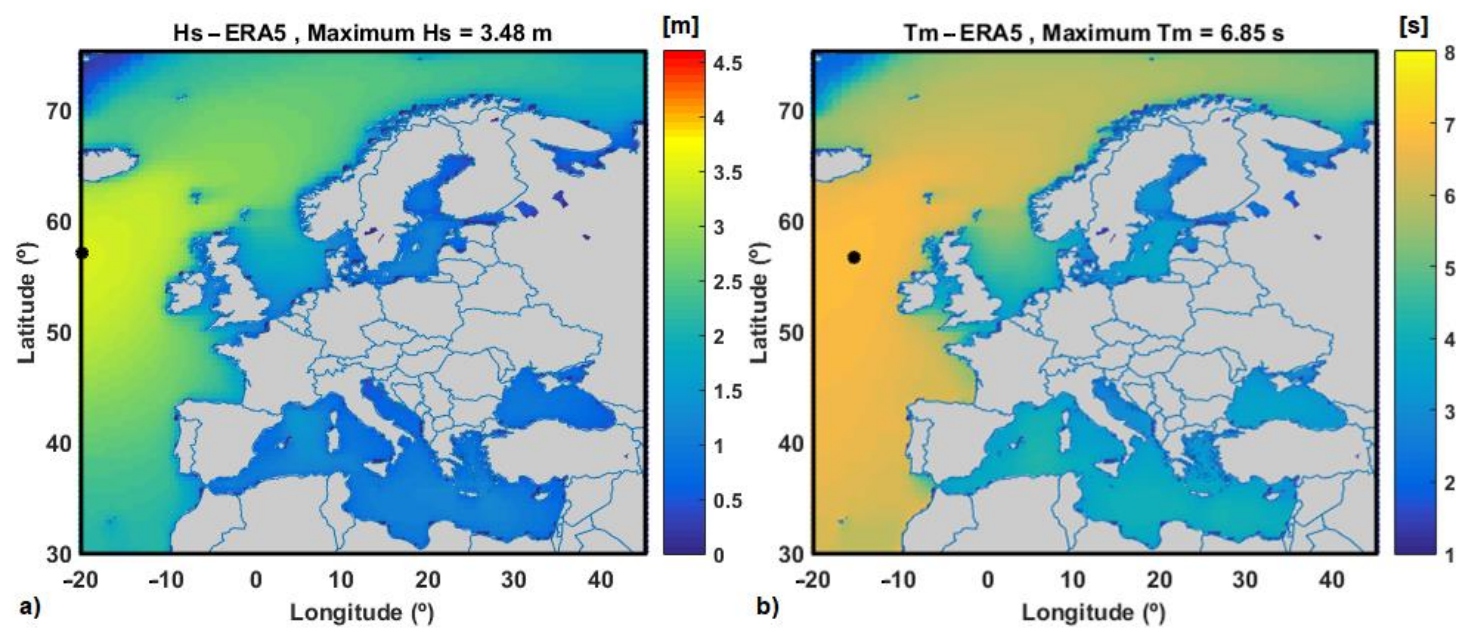

Figure 14. Mean wave conditions for the Europe region in the period 2001-2020: (a) Wave heights; (b) Wave periods.
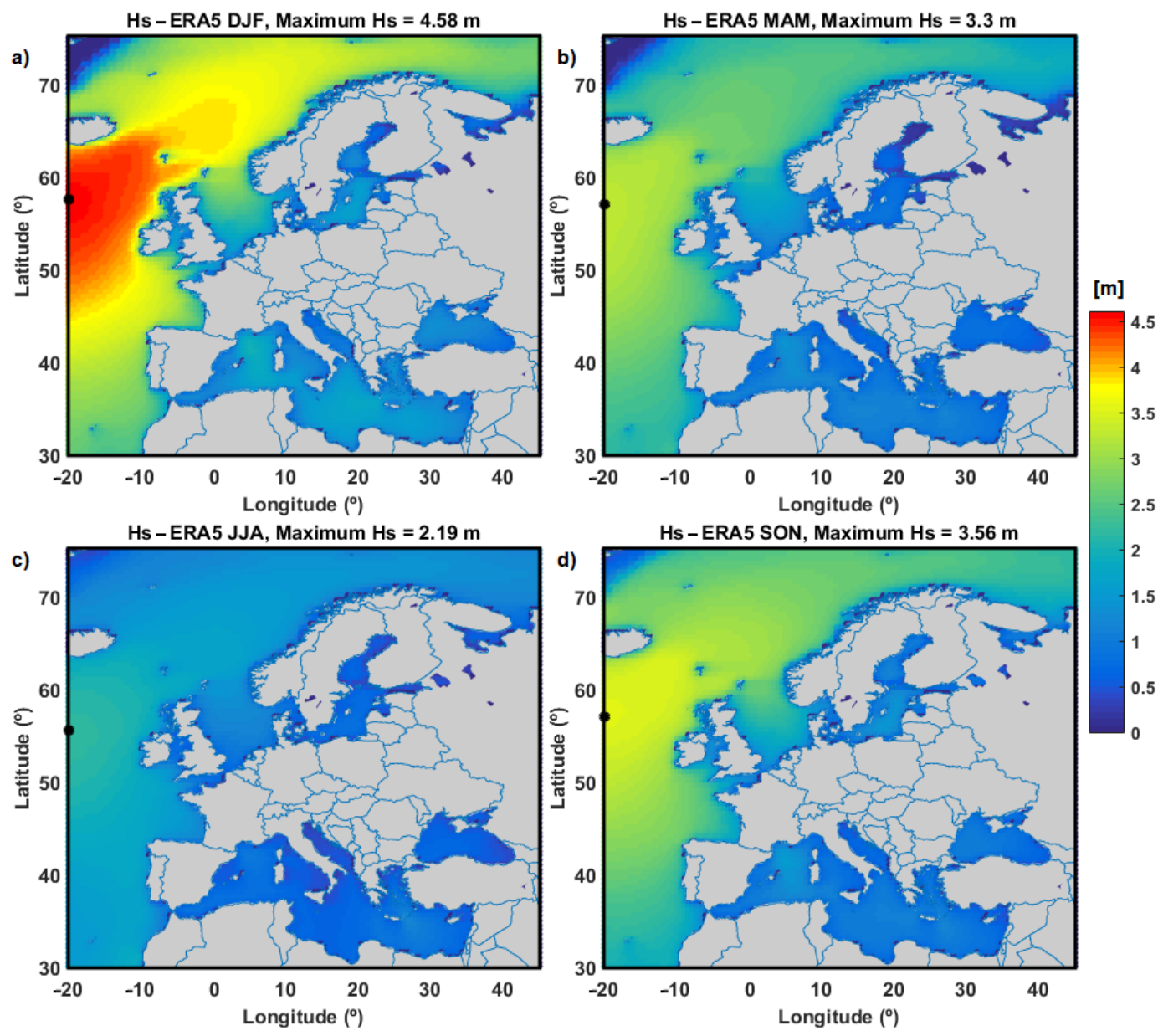

Figure 15. Seasonal variability of the mean significant wave height over the 20-year time interval (from 2001 to 2020) based on ERA5 data: (a) winter (DJF), (b) spring (MAM), (c) summer (JJA), (d) autumn (SON). 

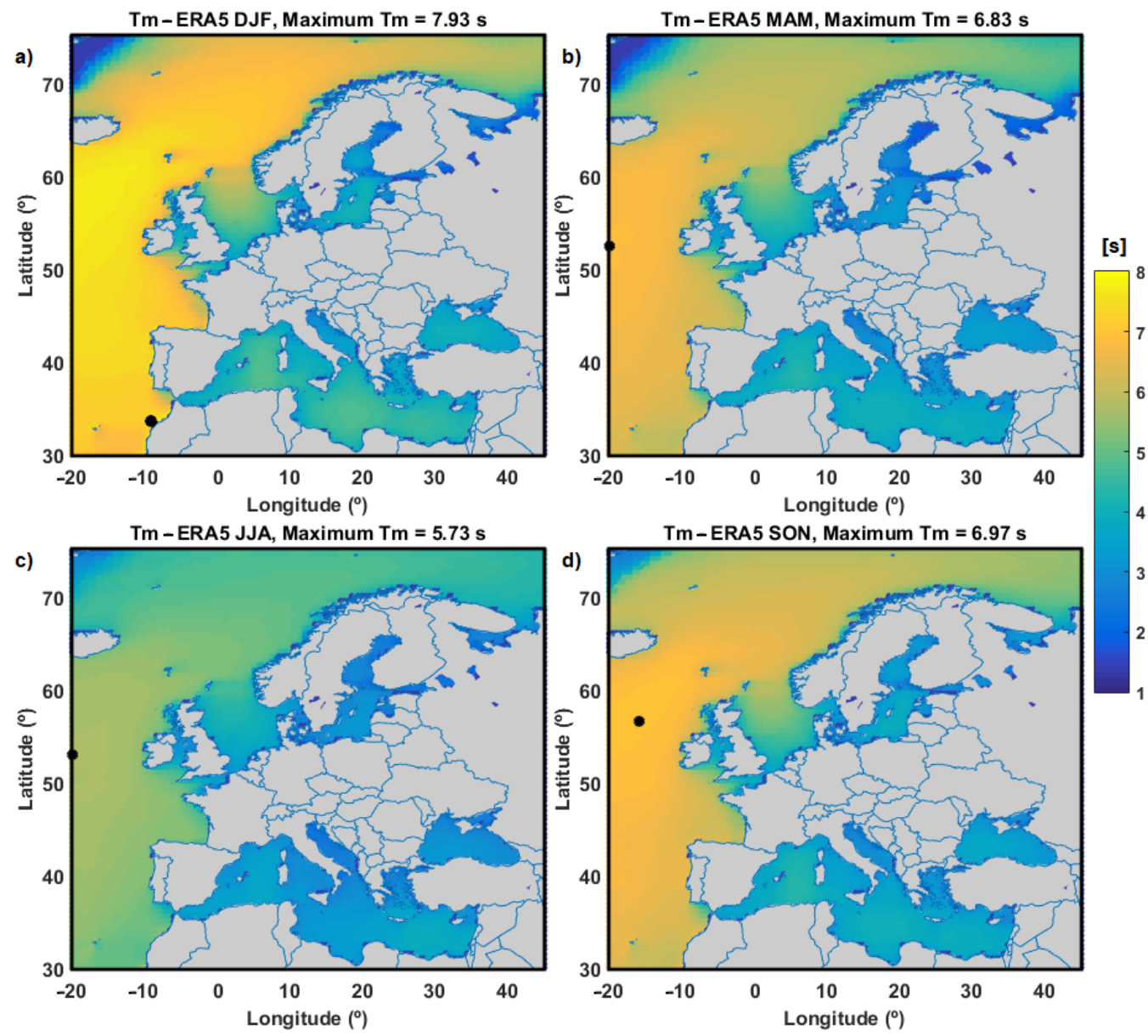

Figure 16. Seasonal variability of the mean wave period over the 20-year time interval (from 2001 to 2020) based on ERA5 data: (a) winter (DJF), (b) spring (MAM), (c) summer (JJA), (d) autumn (SON).

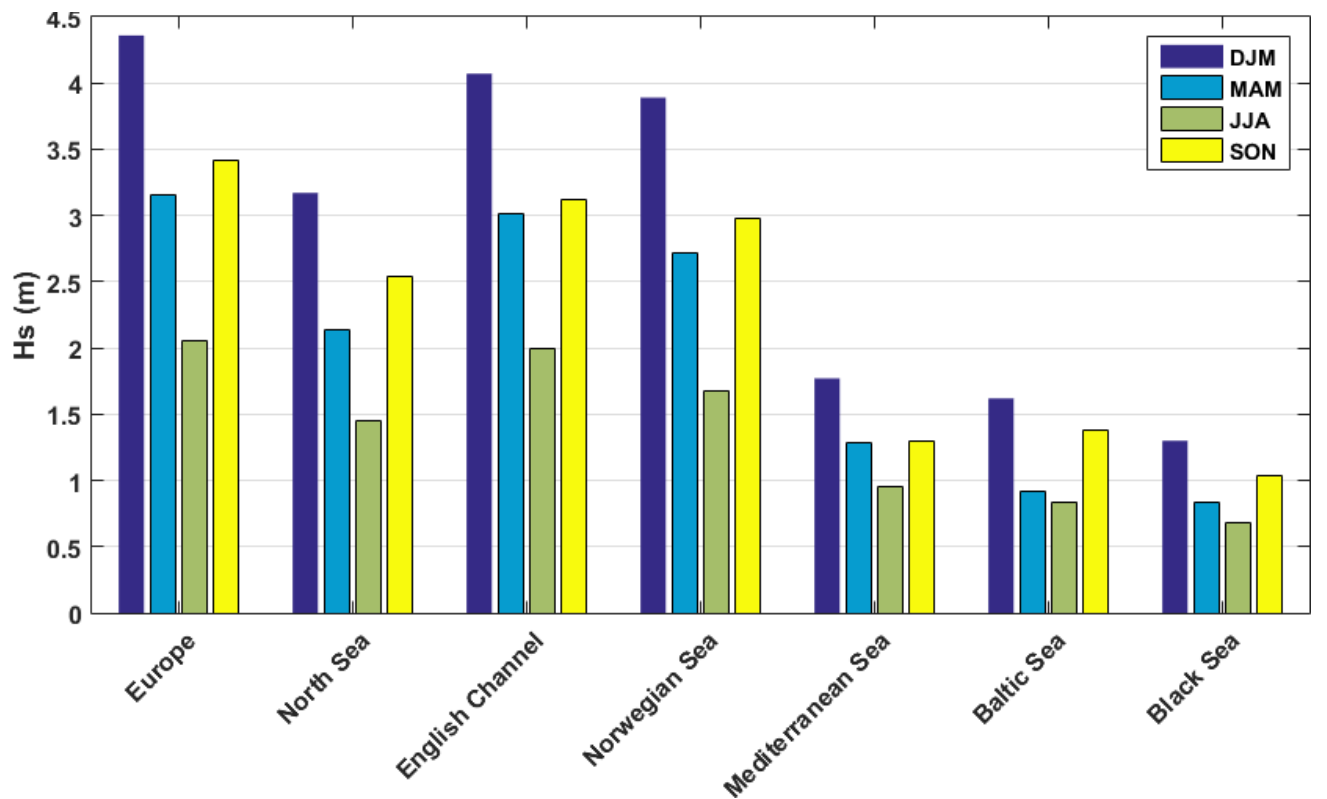

Figure 17. Seasonal characteristics 95th percentile of the mean Hs fields for each area considered.

From Figures 15 and 17, it can be observed that the maximum value of Hs means and percentiles in summer (JJA) are half those encountered in winter (DJF), except in the North Sea where the difference between winter and summer values are even greater. In the 
transition seasons (spring and autumn) there are more balanced maximum values, a little higher in autumn.

The most severe wave conditions are encountered in winter when the highest means of the wave parameters are in the English Channel (3.14 $\mathrm{m}$ for Hs and $6.74 \mathrm{~s}$ for Tm), and the calmest sea states are in the Black Sea where the maximum values are $0.97 \mathrm{~m}$ and $3.62 \mathrm{~s}$, respectively.

As in the case of wind speed analysis, the 50th, 75th, 90th, and 95th percentiles of Hs were computed using the 20-year time series of data available in each point of the ERA5 grid covering the Europe zone. The results are presented in Figure 18, while in Table 4 the maximum values of percentiles for each zone are given. It should be taken into consideration that, in each defined area, the analysis was made considering both information on the sea state conditions near to the coast, and also from the offshore. In order to identify the differences between these areas (nearshore vs. offshore), which sometimes can be high (see for example the Norwegian Sea zone), the figures in which the maps are presented must be also consulted.
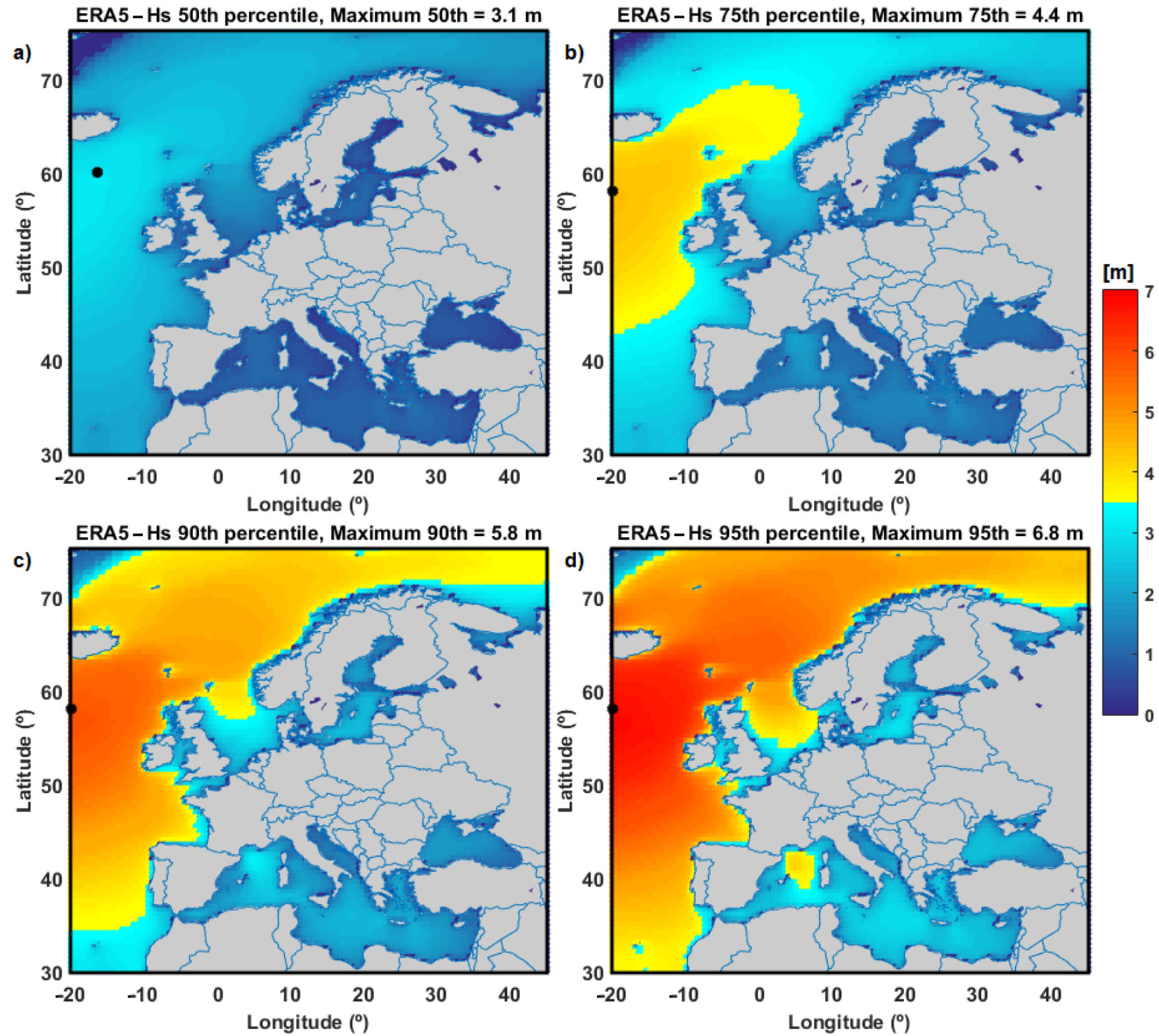

Figure 18. Statistical investigation on wave height conditions: (a) 50th percentile; (b) 75th percentile; (c) 90 th percentile; (d) 95 th percentile. 
Table 4. Maximum values of percentiles computed for Hs in each area considered.

\begin{tabular}{ccccc}
\hline Zone & Max 95th $(\mathbf{m})$ & Max 90th $(\mathbf{m})$ & Max 75th $(\mathbf{m})$ & Max 50th $(\mathbf{m})$ \\
\hline Europe & 6.8 & 5.8 & 4.4 & 3.1 \\
\hline North Sea & 5.9 & 5.1 & 3.8 & 2.7 \\
\hline English Channel & 6.4 & 5.4 & 4.0 & 2.9 \\
\hline Norwegian Sea & 5.6 & 4.8 & 3.7 & 2.6 \\
\hline Mediterranean Sea & 4.0 & 3.2 & 2 & 1.1 \\
\hline Baltic Sea & 2.9 & 2.4 & 1.6 & 1.0 \\
\hline Black Sea & 2.3 & 1.9 & 1.2 & 0.8 \\
\hline
\end{tabular}

From Figure 18 it can be observed very clear that in the Mediterranean Sea the highest values of percentiles (especially 95th and 90th) are in the Gulf of Lion and the Aegean Sea. Also, the western part of the Black Sea and southeastern part of the Baltic Sea present the highest values of these percentiles. It is obvious that in the other zones the highest values are in the vicinity of the Atlantic Ocean.

\subsection{Extreme Wave Conditions along the Maritime Routes}

As in the case of the extreme wind analysis, significant wave height values along the European maritime routes considered in this study were extracted and the results are presented in Figure 19. Table 5 shows the maximum value of the 95th percentile computed on each route.

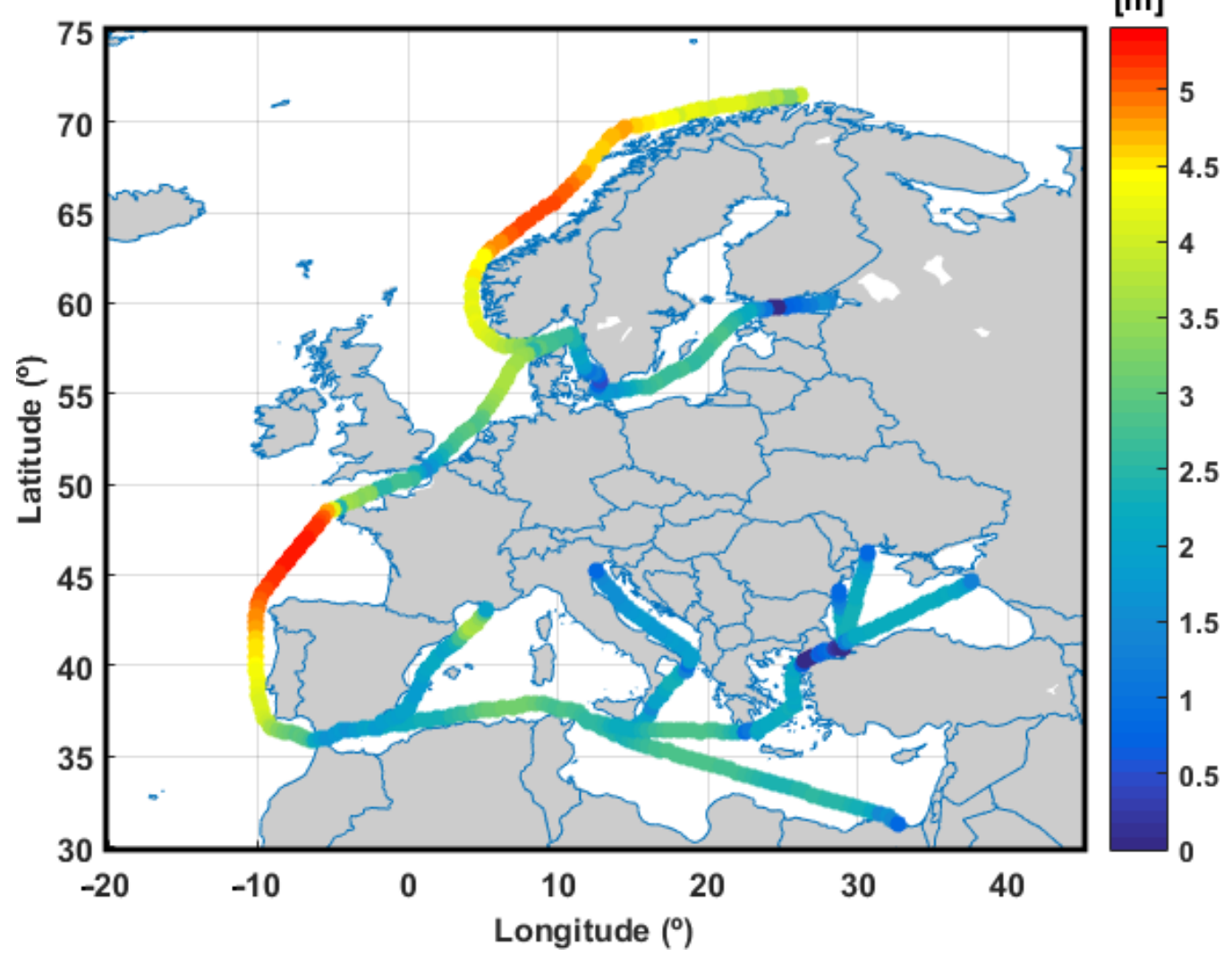

Figure 19. Hs 95th percentile along the European maritime routes. 
Table 5. Maximum Hs 95th percentile on each route considered in this study.

\begin{tabular}{|c|c|c|}
\hline \multicolumn{2}{|c|}{ Routes } & Maximum Hs 95th Percentile (m) \\
\hline \multirow{5}{*}{ Main routes } & $\mathrm{R} 1$ & 5.14 \\
\hline & $\mathrm{R} 2$ & 2.80 \\
\hline & R3 & 3.67 \\
\hline & $\mathrm{R} 4$ & 5.31 \\
\hline & $\mathrm{R} 5$ & 3.19 \\
\hline \multirow{6}{*}{ Secondary routes } & R5a & 3.68 \\
\hline & R5b & 2.35 \\
\hline & R5c & 2.80 \\
\hline & R6a & 2.29 \\
\hline & R6b & 2.31 \\
\hline & R6c & 2.23 \\
\hline
\end{tabular}

As could be expected, the highest values (above $4.5 \mathrm{~m}$ ) of $\mathrm{Hs}$ 95th percentile are on the North Atlantic coasts, on routes R1 (Norwegian Sea) and R4 (south of English Channel), respectively. Although on route $\mathrm{R} 3$ high values of wind speed 95th percentile are met, the maximum value for Hs 95th percentile does not reach $4 \mathrm{~m}$.

\section{Conclusions}

Currently, maritime transport covers about $90 \%$ of world trade, with a strong impact on the economies of the countries in the area where it can take place. During the studied period, a tendency to improve the characteristics of the ships in terms of the amount transported, the reduction of the amount of fuel consumed, and the implementation of methods to reduce pollution were observed. Even with these expensive measures, sea transport remains the most popular and cheapest method of transport.

On the other hand, not only is the transport of goods on an upward trend, but also the marine transportation of people is increasing day by day. The number of regular passengers is doubled during the holidays due to tourists who are becoming more and more interested in traveling along the coastal area. Italy, Greece, and Denmark have the busiest ports in terms of the number of registration vessels, and most quantities of goods were registered in the Netherland and the United Kingdom. Although the Netherlands is in first place in the transport of goods, when it comes to passengers it is in 15th place in Europe, at a fairly large difference from Italy and other countries.

In order to be able to continuously support the development of maritime traffic, the climatic conditions in this area, as well as their extreme events are necessary to be known. Therefore, based on the data extracted from ERA5 database, a series of analyses were performed, to evaluate the mean values, 95th, 90th, 75th, and 50th percentiles, as well as seasonal variations of wind and wave conditions.

Following the study carried out based on the data covering a 20-year period, the areas with the most severe conditions were identified. The most important parameters for the analysis and operability of ships, in terms of climatic conditions, are the significant wave height and the wave period. Both in terms of wind and wave conditions, the North Sea zone and the English Channel region present the highest values due to some areas with severe conditions (northern part of the North Sea zone and the Celtic Sea). The calmest zones seem to be the Black and Baltic seas. However, even in these basins extreme events in the winter season that are dangerous for maritime traffic can appear [7,48-50].

Regarding the maritime routes in the European area, severe conditions are met on the routes that pass through the Norwegian Sea (R1) and on the route that passes through the Gulf of Lion (R5a). Moreover, the seasonal variation is an important factor in analyzing wind conditions, and as expected, the winter season is the windiest season and summer is 
the calmest, with values lower by about $40 \%$. The influence of the North Atlantic Ocean on the North Sea produces extreme conditions at the entrance in this basin, and for this reason, here we encounter high values of significant wave height. In terms of seasonal variation, the same pattern as wind conditions is encountered.

Awareness of wave and wind climate in this region has several benefits, the most important of which would be avoiding hazardous areas and thus reducing accidents, preventing and preparing for crossing different passages, and exploiting them by installing wind and wave farms for electricity production based on renewable sources.

Author Contributions: Conceptualization, A.-M.C. and L.R.; methodology, L.R.; software simulations, validation, analysis and visualization, A.-M.C.; writing-original draft preparation, A.-M.C.; writing final version, L.R.; supervision, L.R. All authors have read and agreed to the published version of the manuscript.

Funding: The work of the first author is supported by the project ANTREPRENORDOC, in the framework of Human Resources Development Operational Programme 2014-2020, financed from the European Social Fund under the contract number 36355/23.05.2019 HRD OP/380/6/13-SMIS Code: 123847. The work of the second author was carried out in the framework of the research project DREAM (Dynamics of the REsources and technological Advance in harvesting Marine renewable energy), supported by the Romanian Executive Agency for Higher Education, Research, Development and Innovation Funding - UEFISCDI, grant number PN-III-P4-ID-PCE-2020-0008.

Institutional Review Board Statement: Not applicable.

Informed Consent Statement: Not applicable.

Data Availability Statement: Not applicable.

Acknowledgments: The data used in this study are openly available. ERA5 data used in this study were obtained from the ECMWF data server.

Conflicts of Interest: The authors declare no conflict of interest.

\section{References}

1. Vettor, R.; Soares, C.G. Characterization of the expected weather conditions in the main European coastal traffic routes. Ocean. Eng. 2017, 140, 244-257. [CrossRef]

2. Chirosca, A.; Rusu, L. Sea state characteristics and the maritime traffic in the European Seas. In Proceedings of the 20th International Multidisciplinary Scientific GeoConference SGEM, Albena, Bulgaria, 18-24 August 2020; Volume 20, pp. 863-870. [CrossRef]

3. Rusu, E. A 30-year projection of the future wind energy resources in the coastal environment of the Black Sea. Renew. Energy 2019, 139, 228-234. [CrossRef]

4. Lobeto, H.; Menendez, M.; Losada, I.J. Future behavior of wind wave extremes due to climate change. Sci. Rep. 2021, 11, 7869. [CrossRef] [PubMed]

5. Lavidas, G.; Polinder, H. North sea wave database (NSWD) and the need for reliable resource data: A 38 year database for metocean and wave energy assessments. Atmosphere 2019, 10, 551. [CrossRef]

6. Novo-Corti, I.; Gonzalez-Laxe, F. The integrated offshore grid in Europe: Exploring challenges for regional energy governance. Energy Res. Soc. Sci. 2019, 52, 55-67.

7. Divinsky, B.V.; Fomin, V.V.; Kosyan, R.D.; Rather, Y.D. Extreme wind waves in the Black Sea. Oceanologia 2020, 62, 23-30. [CrossRef]

8. Onea, F.; Rusu, L. Long-Term Analysis of the Black Sea Weather Windows. J. Mar. Sci. Eng. 2019, 7, 303. [CrossRef]

9. Pastor, F.; Valiente, J.A.; Khodayar, S. A Warming Mediterranean: 38 Years of Increasing Sea Surface Temperature. Remote Sens. 2020, 12, 2687. [CrossRef]

10. Castells, M.; Martínez de Osés, F.X.; Usabiaga, J.J. Analysis of the Prevailing Weather Conditions Criteria to Evaluate the Adoption of a Future ECA in the Mediterranean Sea. In Marine Navigation and Safety of Sea Transportation; Weintrit, A., Ed.; CRC Press Taylor \& Francis Group: Boca Raton, FL, USA, 2013; pp. 161-165. [CrossRef]

11. Lejeusne, C.; Chevaldonne, P.; Pergent-Martini, C.; Boudouresque, C.F.; Perez, T. Climate change effects on a miniature ocean: The highly diverse, highly impacted Mediterranean Sea. Trends Ecol. Evol. 2010, 25, 250-260. [CrossRef]

12. Ganea, D.; Amortila, V.; Mereuta, E.; Rusu, E. A joint evaluation of the wind and wave energy resources close to the Greek Islands. Sustainability 2017, 9, 1025. [CrossRef]

13. Barbariol, F.; Davison, S.; Falcieri, F.M.; Ferretti, R.; Ricchi, A.; Sclavo, M.; Benetazzo, A. Wind Waves in the Mediterranean Sea: An ERA5 Reanalysis Wind-Based Climatology. Front. Mar. Sci. 2021, 8, 760614. [CrossRef] 
14. Onea, F.; Ruiz, A.; Rusu, E. An Evaluation of the Wind Energy Resources along the Spanish Continental Nearshore. Energies 2020, 13, 3986. [CrossRef]

15. Lensu, M.; Goerlandt, F. Big maritime data for the Baltic Sea with a focus on the winter navigation system. Mar. Policy 2019, 104, 53-65. [CrossRef]

16. Bonaduce, A.; Stanevra, J.; Beherens, A.; Bidlot, J.; Wilcke, R.A.I. Wave Climate Change in the North Sea and Baltic Sea. J. Mar. Sci. Eng. 2019, 7, 166. [CrossRef]

17. Suselj, K.; Sood, A.; Heinemann, D. North Sea near-surface wind climate and its relation to the large-scale circulation patterns. Theor. Appl. Climatol 2010, 99, 403-419. [CrossRef]

18. Bell, R.J.; Gray, S.L.; Jones, O.P. North Atlantic storm driving of extreme wave heights in the North Sea. J. Geophys. Res. Oceans 2017, 122, 3253-3268. [CrossRef]

19. Mosquera, I.A.; Sagrilo, L.V.; Videiro, P.M.; Sousa, F. Assessing the impact of climate change on the fatigue life of offshore structures. J. Offshore Mech. Arct. Eng. 2021, 1-35. [CrossRef]

20. Mork, K.A.; Skagseth, O.; Soiland, H. Recent Warming and Freshening of Norwegian Sea Observed by Argo Data. J. Clim. 2019, 32, 36-3705. [CrossRef]

21. Dickson, B.; Østerhus, S. One hundred years in the Norwegian Sea. Nor. Geogr. Tidsskr.-Nor. J. Geogr. 2007, 61, 56-75. [CrossRef]

22. Simonsen, M.; Gossling, S.; Walnum, J.H. Cruise ship emissions in Norwegian waters: A geographical analysis. J. Transp. Geogr. 2019, 78, 87-97. [CrossRef]

23. Lemos, G.; Menendez, M.; Semedo, A.; Miranda, P.M.; Hemer, M. On the decreases in North Atlantic significant wave heights from climate projections. Clim. Dyn. 2021, 57, 2301-2324. [CrossRef]

24. Bricheno, L.M.; Wolf, J. Future wave conditions of Europe, in response to high-end climate change scenarios. J. Geophys. Res. Oceans 2018, 123, 8762-8791. [CrossRef]

25. Rodrigue, J.P. Maritime transport. In The International Encyclopedia of Geography: People, the Earth, Environment and Technology; Richardson, D., Castree, N., Goodchild, M.M., Kobayashi, A., Liu, W., Marston, R.A., Eds.; John Wiley \& Sons, Ltd.: Hoboken, NJ, USA, 2017; Volume 15, pp. 1-7. [CrossRef]

26. Squire, D. The Hazards of Navigating The Dover Strait (Pas-de-Calais) Traffic Separation Scheme. J. Navig. 2003, 56, 195-210. [CrossRef]

27. European Marine Observation and Data Network (EMODnet). Available online: https://www.emodnet-humanactivities.eu/ (accessed on 12 December 2021).

28. Dedecca, J.G.; Hakvoort, R.A.; Herder, P.M. Maritime Transport and Trade: The Impact of European Transport Policy. An Overview of Maritime Freight Transport Patterns. Eur. Res. Stud. 2009, XII, 131-147.

29. Eurostat Database. Available online: https:/ / ec.europa.eu/eurostat/data/database (accessed on 10 July 2021).

30. Chirosca, A.; Rusu, L. Statistical analysis of the types of ships that have crossed the European ports in the last decade. In Proceedings of the 20th International Multidisciplinary Scientific GeoConference SGEM, Albena, Bulgaria, 18-24 August 2020; Volume 20, pp. 249-256. [CrossRef]

31. ECMWF Reanalysis v5 (ERA5). Available online: https:/ /www.ecmwf.int/en/forecasts/dataset/ecmwf-reanalysis-v5 (accessed on 12 July 2021).

32. Hersbach, H.; Bell, B.; Berrisford, P. The ERA5 global reanalysis. QJR Meteorol Soc. 2020, 146, 1999-2049. [CrossRef]

33. Dee, D.P.; Uppala, S.M.; Simmons, A.J.; Berrisford, P.; Poli, P.; Kobayashi, S.; Andrae, U.; Balmaseda, A.M.; Balsamo, G.; Bauer, P.; et al. The ERA-Interim reanalysis: Configuration and performance of the data assimilation system. Q. J. R. Meteorol. Soc. 2011, 137, 553-597. [CrossRef]

34. Buatois, A.; Gibescu, M.; Rawn, B.G.; Van der Meijden, A.M. Analysis of North Sea offshore wind power variability. Resources 2014, 3, 454-470. [CrossRef]

35. Bentamy, A.; Croize-Fillon, D. Spatial and temporal characteristics of wind and wind power off the coasts of Brittany. Renew. Energy 2014, 66, 670-679. [CrossRef]

36. Karagali, I.; Badger, M.; Hahmann, A.N.; Peña, A.; Hasager, C.B.; Sempreviva, M.A. Spatial and temporal variability of winds in the Northern European Seas. Renew. Energy 2013, 57, 200-210. [CrossRef]

37. Moemken, J.; Reyers, M.; Feldmann, H.; Pinto, J.G. Future changes of wind speed and wind energy potentials in EURO-CORDEX ensemble simulations. J. Geophys. Res. Atmos. 2018, 123, 6373-6389. [CrossRef]

38. Diaconita, A.; Andrei, G.; Rusu, L. New insights into the wind energy potential of the west Black Sea area based on the North Sea wind farms model. Energy Rep. 2021, 7, 112-118. [CrossRef]

39. Akpınar, A.; Bingölbali, B.; van Vledder, G.P. Wind and wave characteristics in the Black Sea based on the SWAN wave model forced with the CFSR winds. Ocean Eng. 2016, 126, 276-298. [CrossRef]

40. Rusu, L. The wave and wind power potential in the western Black Sea. Renew. Energy 2019, 139, 1146-1158. [CrossRef]

41. Koletsis, I.; Kotroni, V.; Lagouvardos, K.; Soukissian, T. Assessment of offshore wind speed and power potential over the Mediterranean and the Black Seas under future climate changes. Renew. Sustain. Energy Rev. 2016, 60, 234-245. [CrossRef]

42. Soukissian, T.; Karathanasi, F.; Axaopoulos, P.; Voukouvalas, E.; Kotroni, V. Offshore wind climate analysis and variability in the Mediterranean Sea. Int. J. Climatol. 2018, 38, 384-402. [CrossRef]

43. Menendez, M.D.C.R.; García-Díez, M.; Fita, L.; Fernández, J.; Méndez, F.J.; Gutiérrez, J.M. High-resolution sea wind hindcasts over the Mediterranean area. Clim. Dyn. 2014, 42, 1857-1872. [CrossRef] 
44. Vettor, R.; Soares, C.G. Assessment of the storm avoidance effect on the wave climate along the main North Atlantic routes. J. Navig. 2016, 69, 127-144. [CrossRef]

45. Echevarria, E.R.; Hemer, M.A.; Holbrook, N.J. Seasonal variability of the global spectral wind wave climate. J. Geophys. Res. Oceans 2019, 124, 2924-2939. [CrossRef]

46. Rusu, L.; Rusu, E. Evaluation of the worldwide wave energy distribution based on ERA5 data and altimeter measurements. Energies 2021, 14, 394. [CrossRef]

47. Takbash, A.; Young, I.R. Long-Term and Seasonal Trends in Global Wave Height Extremes Derived from ERA-5 Reanalysis Data. J. Mar. Sci. Eng. 2020, 8, 1015. [CrossRef]

48. Rutgersson, A.; Kjellström, E.; Haapala, J.; Stendel, M.; Danilovich, I.; Drews, M.; Jylhä, K.; Kujala, P.; Larsén, X.G.; Halsnæs, K.; et al. Natural hazards and extreme events in the Baltic Sea region. Earth Syst. Dyn. Discuss. 2021, 1-80, preprint. [CrossRef]

49. Bernardino, M.; Rusu, L.; Soares, C.G. Evaluation of extreme storm waves in the Black Sea. J. Oper. Oceanogr. 2021, 14, 114-128. [CrossRef]

50. Soomere, T.; Räämet, A. Spatial patterns of the wave climate in the Baltic Proper and the Gulf of Finland. Oceanologia 2011, 53, 335-371. [CrossRef] 